Portland State University

PDXScholar

\title{
The prosecutors of Socrates and the political motive theory
}

Thomas Patrick Kelly

Portland State University

Follow this and additional works at: https://pdxscholar.library.pdx.edu/open_access_etds

Part of the Intellectual History Commons, and the Political History Commons Let us know how access to this document benefits you.

\section{Recommended Citation}

Kelly, Thomas Patrick, "The prosecutors of Socrates and the political motive theory" (1981). Dissertations and Theses. Paper 2692.

https://doi.org/10.15760/etd.2689

This Thesis is brought to you for free and open access. It has been accepted for inclusion in Dissertations and Theses by an authorized administrator of PDXScholar. Please contact us if we can make this document more accessible: pdxscholar@pdx.edu. 
AN ABSTRACT OF THE THESIS OF Thomas Patrick Kelly for the Master of Arts in History presented February 26, 1981.

Title: The Prosecutors of Socrates and The Political Motive Theory.

APPROVED BY MEMBERS OF THE THESIS COMMITTEE:

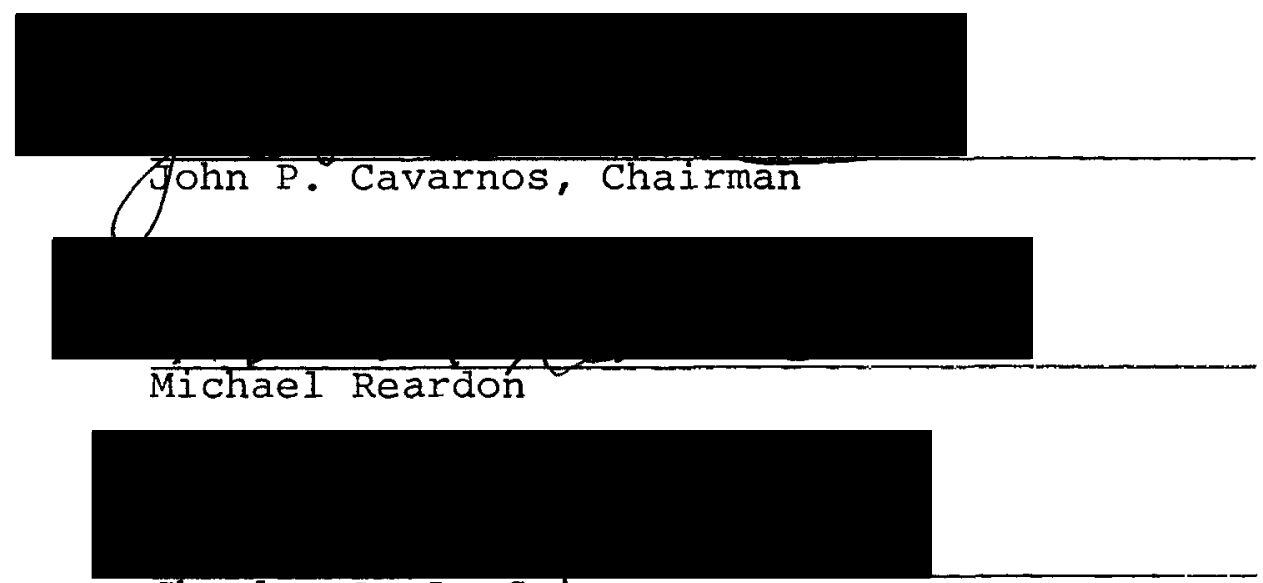

Charles A. Le Guin

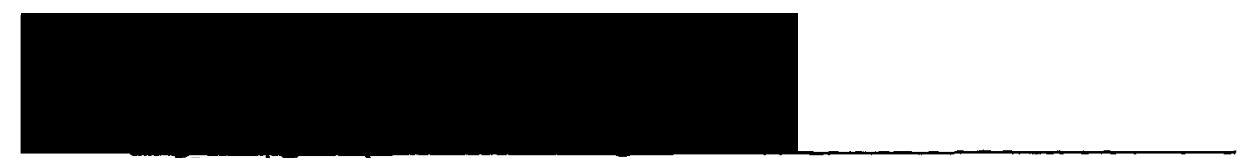

Roderic Diman

This thesis presents a critical analysis of the historical roles assigned to the prosecutors of Socrates by modern historians .

Ancient sources relating to the trial and the principles involved, and modern renditions, especially those of John Burnet and A. E. Taylor, originators of the theory that the trial of Socrates was politically motivated, are critically 
analyzed and examined.

The thesis concludes that the political motive theory is not supported by the evidence on which it relies. 
THE PROSECUTORS OF SOCRATES

AND THE POLITICAL MOTIVE THEORY

by

THOMAS PATRICK KELLY

A thesis submitted in partial fulfillment of the requirements for the degree of

MASTER OF ARTS

in

HISTORY

Portland State University

1981 
TO THE OFFICE OF GRADUATE STUDIES AND RESEARCH:

The members of the Committee approve the thesis of

Thomas Patrick Kelly presented February 26, 1981.

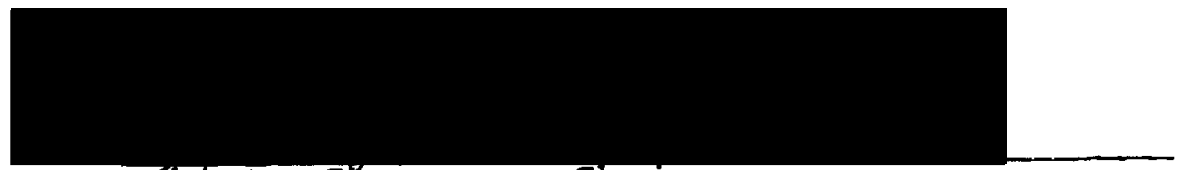

Fohf P. Cavarnos, Chairman

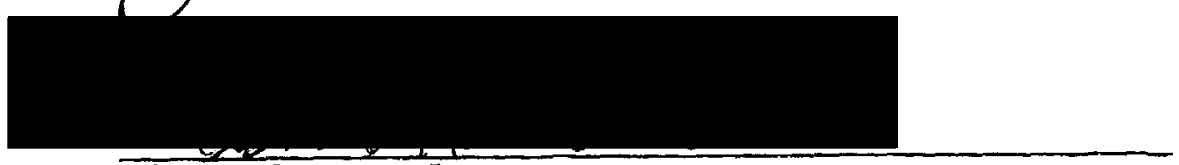

Michael Reardon

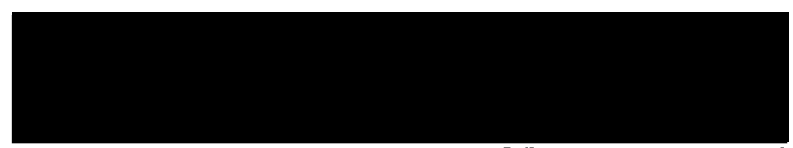

Charles A. LeGuin

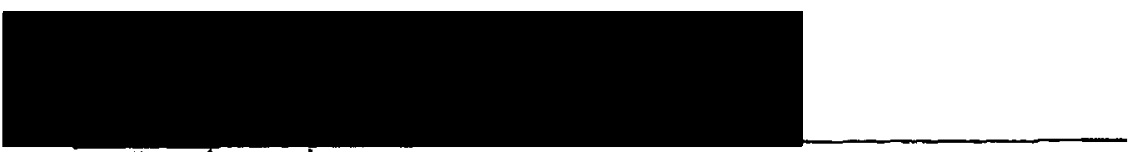

Roderic Diman

APPRPVAिD :

Frederick M. Nunn, Head, Department of History

Stanley E. Rauch, Dean of Graduate Studies and Research 
It was to break down this terrible chain of facts, and to show that each piece of evidence when taken separately was unproved and fantastic, that I undertook the case. 
PREFACE

This thesis will critically assess and examine current views regarding the prosecutors of Socrates, particularly with respect to how they are perceived by proponents of the theory that the trial of Socrates was politically motivated. It will be argued that the portraits of both Anytus and Meletus are not historical, but have been rendered after the procrustean fashion to fit the theory. A re-examination of ancient sources and an analysis of arguments will demonstrate that the political motive theory cannot be ascertained from a study of the evidence relating to the men who undertook the trial. Consequently, if the motive cannot be pinned to the prosecution, then the efficacy of the theory is clearly in doubt.

Ancient writers all but ignored the prosecutors of Socrates. The pictures that remain are like puzzles with ninety percent of the pieces missing. But the ingenuity of modern scholarship has corrected the deficiency: with so little to go on, much has been made of it. Accordingly, the terms used to describe Meletus and Anytus are few and seldom vary from one author to another; they are employed over and over again like epic epithets. In order to break up this association, therefore, it has seemed necessary to chip away at their meaning from any angle to which they appear vulnerable; and 
these have proved considerable. This task, moreover, can be accomplished without squarely facing the issue of whether our knowledge of the prosecutors is based on fact or fiction. The views attacked here collapse under the weight of their own criteria.

This thesis has been organized according to the five divisions of forensic oratory.

The Introduction serves to orient the theory as a preconceived notion based on the study of Socrates, to which the prosecutors' roles have been assigned largely after the fact.

The second part, the Statement, sets forth current opinion regarding the three prosecutors and how they are tied in to the terms of the actual indictment.

The Refutation section provides a detailed critique of the second part. Beginning with the identity of Meletus, it moves on to consider his improbable association with Anytus, and ends with a lengthy analysis of Anytus, himself, the central figure of the prosecution, on whose account so much of the theory depends.

Following oratorical tradition, part four, the Digression, will depart from the proper subject to present a socio-economic comparison of Anytus and Socrates. This short sketch will develop themes suggested in the earlier parts and is designed to ground the differences between the two in terms other than ideological. 
The last part, the Peroration, offers a summary of the main points of the thesis.

\section{ACKNOWLEDGMENT}

I would like to express my gratitude to John Carvarnos for the guidance, generosity and support he has unfailingly provided me throughout my career at Portland State; and also to Mike Reardon, whose aid and assistance over the years has been timely and rewarding. 
TABLE OF CONTENTS

PAGE

PREFACE and ACKNOWLEDGMENT - • • • • • • • • • • • • iv

CHAPTER

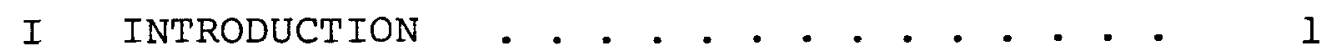

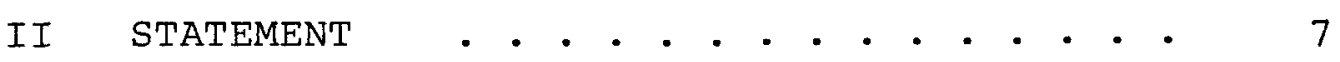

The Prosecutors . . . . . . . . . 7

Additional Note: Variations on

A Theme . . . . . . . . . . . 16

III REFUTATION • . • • . • • • • • • • • 20

The Identity of Meletus . . . . . . 20

His Association with Anytus . . . . 27

Anytus . • . • • • • • • • • • 33

His Prominence 34

As a Moderate Democrat 36

As Chief Promoter of the Amnesty 47

The Theory Comes Unglued . . . . . . 54

IV DIGRESSION . . . . . . . . . . . . . 67

Socrates and Anytus Compared . . . . 67

Anytus' Selection of Meletus . . . . 74

V PERORATION: A SUMMARY . . . . . . . 79

BIBLIOGRAPHY . . . . . . . . . . . . . . . . . . 
CHAPTER I

INTRODUCTION

From the beginning the trial of socrates has served as the battleground for the dispute over the "historical Socrates." The trial is studied in a charged atmosphere with the focus of debate rivetted on the controversial words and behavior of the legendary defendant. The men responsible for bringing the whole affair into being--Meletus, Anytus and Lycon--the prosecutors of Socrates, are cursorily introduced and as quickly dismissed in order to bring the star of the proceedings back into focus. What is said about them is overwhelmed by the rapt fascination with socrates. It is as though to understand socrates--and his time--is to know why he was tried and executed. Consequently:

When the aristocratic-oligarchic party lost out to the democratic forces in May of 403 , Socrates, who was probably considered one of the most influential intellectual leaders of the aristocrats, was hopelessly doomed.

The individuality of the prosecutors is incidental, over them looms the shadow and enigma of Socrates. Given the man and the time, the trial was inevitabie.

This belief in the inevitability of the trial is

${ }^{1}$ Anton-Hermann Chroust, Sorrates, Man And Myth (Notre Dame, Indiana: University of Notre Dame Press, 1957), p. 184. 
implicit in the Apology of Plato. There Socrates (Plato?) claims his prosecution was made possible as a resultof alongstanding prejudice against him, which a single courtroom defense is, admittedly, not likely to overturn. All his life long he has been slandered by men envious of his reputation for wisdom. Meletus, Anytus and Lycon represent professions most often made the butt of his peculiar dialectical skills: the poets, craftsmen (and statesmen) and rhetoricians who resent his smug manner and impertinent ridicule. Beyond this, Meletus is barely out of his teens and ambitious to make a name for himself; Anytus wants him out of the way because the example he sets has a corruptive influence on young men; Lycon--we hear nothing particular about Lycon. Plato admirably defends Socrates against all these charges, he makes them appear petty and spiteful. In subsequent dialogues, we get to see Socrates in action, doing what he does best; his (Plato's) logical skills are truly remarkable. Here we have a powerful intellect; a man capable of eliciting strong reactions in people, which, if built up over the years, might one day break out in a lawsuit.

For those who accept the Apology as a faithful report of what Socrates actually said in his defense, the above scenario should sufficiently explain the motive for the prosecution. The fervor with which they jawbone for its authenticity is quite remarkable. 
(the Apology) is, in its main features, a reproduction of what was actually said. So much is, indeed, now admitted by most of the scholars whose names carry most weight (e.g. Ritter and WilamowitzMoellendorff). Misrepresentation ... would have been suicidal for its author. 2

There can be little doubt that it (the Apology) is a faithful record in substance ...; it would have been stupid to misrepresent facts which were familiar to a great part of the Athenian people.

Having thus argued, one would fully expect the above authors to be foursquare behind the Apology's account of the motives of the prosecution, but no--here is where the conflict over the Socrates of Plato and the Socrates of Xenophon is resolved.

Xenophon's portrait of Socrates, in his Apology and the Memorabilia, is generally rejected as being far inferior to that of Plato's. His is simply not that of a great man, not the stuff that legends are made out of anyway. But he does have something that Plato neglects to mention in the Apology--a motive worthy of the man. In the Memorabilia Xenophon quotes from a pamphlet written by an "unnamed accuser," that charges Socrates, inter alia, with antidemocratic activities, inciting to revolution (two of them, in fact, one in 411 and the other in 403), consorting with the enemy and other crimes injurious to the moral fabric of society.

2A. E. Taylor, Socrates (Garden City, New York: Doubleday Anchor Books, 1952), p. 30 .

${ }^{3}$ Hugh Tredennick (trs.), Plato, The Last Days of Socrates (New York: Penguin Books, 1954)., p. 12. Underscores are mine. 
These accusations have been seized on with a fervor rivalling that with which the Apology was clutched to the breast. Criminal indictment for political activities prior to 403 had been specifically banned by the Amnesty declared in the aftermath of the counter-revolution of 403 that restored the democrats to power. The Act of Oblivion, which formally introduced the Amnesty, prohibited recriminatory trials against neutral parties who had remained in the city under the oligarchic revolutionary government. Socrates was such a party; he also, at one time, had been an intimate associate of critias and Charmides, leaders of the revolutionary government. The injunction of the Amnesty--it is said--would explain why these charges could not be entertained in an indictment against socrates. The generality of the actual indictment and Socrates' references in the Apology to "old accusers" are advanced as evidence that Socrates' doubtful political loyalty lay at the root of his prosecution.

Thus, the pamphlet of Polycrates is seen as a companion-piece to the Apology of Plato: the one presents the case the prosecution would have made had it not been prevented by the Amnesty from doing so, while the other purports to be the defense actually delivered by Socrates in court. Curiously, no one argues that it would have been "stupid" or "suicidal" for Polycrates to have misrepresented the true motives for the prosecution because many of those who had been at the trial would have been able to impugn the charges 
set out in his pamphlet. Nor does anyone asseverate that the pamphlet of Polycrates provides the most secure foundation for our reconstruction of the "historical" Anytus and Meletus. ${ }^{4}$ Without so much as sending up a flare, the accusations of Polycrates are accepted as historical, and the fate of Anytos, in particular, and Meletus is that, henceforth, they are aligned with these views.

Here is where the whole political motive theory comes into problems. Very little is known about Anytus and Meletus. So little is known of Lycon that he is rarely mentioned. Plato and Xenophon in their zeal to portray (and defend?) Socrates seldom refer to his accusers. Nor do they suggest that they were spurred into suing as a result of political concerns (for that matter, neither does anyone else). Political motive theorists have had to scavenge from other sources in order to wedge these men into the motive. What has resulted is a scenario worthy less of Socrates than of Rube Goldberg.

It is this "historical" picture of Anytus and Meletus which is under attack here. Composed entirely out of circumstantial elements, it relies on ambiguous terminology, innuendo, character assassination, mistaken identity, smear

4 "(the Apology) provide(s) the most secure foundation for our reconstruction of 'the historical Socrates. " John Burnet (ed.), Plato's Euthyphro, Apology of Socrates and Crito (Oxford: The Clarendon Press, 1924), p. 64. 
tactics and specious reasoning to succeed. And also the shadow of socrates to keep it out of focus. 
CHAPTER II

STATEMENT

One of the consequences of preferring a motive because it seems worthy of the legend of socrates is that it must also be made worthy of the prosecution--or better, that the prosecution be made worthy of the motive.

Anytus, the man responsible for instigating the proceedings, was a democratic leader exiled during the reign of the Thirty Tyrants (404-403). Along with Thrasybulus, he helped organize the other exiles into a counter-revolutionary army that succeeded in ousting the tyrants and restoring the democracy. At the time of the trial (399) he had already been elected to several high offices in the new government and was one of the most powerful and influential men in the city. From the Meno we learn of his contempt for sophists and of his irritation with socrates for the latter's criticisms of revered statesmen of the old democracy. His prosecution of Socrates is believed to have been actuated by purely patriotic motives. Another story tells of him being annoyed at socrates because the latter ridiculed him for forbidding his son to converse with sophists and sending him to work as a tanner in the family business. In an elaborated version of this story, we are told that Anytus would have 
been willing to drop the suit had Socrates left off his criticisms of cobblers and tanners. This tradition indicating that personal pique was at the bottom of the prosecution is generally dismissed as a fiction, "invented probably by some Socratics in order to avenge their master." 5 In any case, in the Apology he is said to have undertaken the suit on behalf of the craftsman and statesmen. In order to keep the litigation from having the appearance of a political trial, he recruited another man, Meletus, to swear out the indictment under his name and appear in court as the principal prosecutor.

Based on a speech that survives in the works of Lysias (VI), Meletus is said to have been a member of the Eumolpidae, a priestly clan whose role in the Eleusian Mysteries had been scandalously parodied by Alcibiades in the notorious affair known as the "profanation of the mysteries." This scandal had occurred in 415 on the eve of departure of the Athenian Armadatosicily; during the same night a number of sacred Hermae statues had been mutilated and several known associates of Socrates were subsequently implicated in the

${ }^{5}$ Chroust, op. cit., p. 37. Some, like Phillipson, The Trial of Socrates. (London: Stevens \& Sons, Ltd., 1928), p. $208 \mathrm{f}$, usually give the tradition second-billing to the political motive, and would probably concur with M. I. Finley's assessment that "(Anytus') participation creates a strong presumption that the prosecution was a carefully thought through step, not a merely frivolous or petty persecution." M. I. Finley, "Socrates And Athens," Aspects of Antiquity (New York: The Viking Press, 1969), p. 61. 
crime. Feelings over the double sacrilege were still high in 399 as witnessed by the trial of Andocides, who had been granted immunity for his testimony in the affair. His prosecution in 399 on a related crime was also conducted by Meletus. Anytus is believed to have recruited Meletus because he was young, unknown to socrates and a religious fanatic. Since the charge against socrates was one of irreligion, it is believed he pursued the case with a will, for which he is roundly vilified. His father was a minor tragic poet and Socrates' criticisms of the poets is thought to have provided added incentive.

According to the Apology, Lycon appeared at the trial as a representative of the rhetoricians. Diogenes Laertius (II. 39) calls him a demagogue, which identifies him as a politician. Some ${ }^{6}$ have identified him with the Lycon whose son, Autolycus, was killed by a spartan garrison during the reign of the Thirty. Socrates' past association with Critias and Charmides, leaders of the Thirty, is thought to have provoked the father of Autolycus into joining the prosecution. As a professional orator he would have been skilled in the knowledge of how to work a jury.

Having gathered his team of prosecutors, Anytus induced Meletus to introduce the following indictment against socra-

${ }^{6}$ Ibid.; p. 36. Burnet, op. cit., p. 151 (36a8) denies the identification. 
tes :

This indictment and affidavit is sworn by Meletus the son of Meletus of Pitthos, against Socrates, the son of Sophroniscus of Alopece: Socrates is guilty of refusing to recognize the gods recognized by the state and of introducing other new divinities. He is also guilty of corrupting the youth. The penalty demanded is death.

Socrates, in the Apology, links these charges together, to wit, that he is guilty of teaching irreligion to the young. But those who adhere to the political motive theory, following Xenophon in the Memorabilia, treat them as two separate counts. The first count, regarding his failure to recognize the gods of the state, is seen as a clear attempt to smear the reputation of Socrates with the imputation that he is a professional sophist, that is to say, "that he teaches his pupils about things in the heavens and below the earth, and to disbelieve in gods, and to make the weaker argument defeat the stronger." ( teaching was not forbidden by the law Socrates was accused of having violated. This, however, had not always been the case. In 429 Anaxagoras was indicted according to the decree of Diopeithes, "to the effect that anybody who did not believe in the gods or taught theories about celestial phenomena should be liable to prosecution." (Plutarch, Pericles 32) At the time this decree had been framed specifically to

${ }^{7}$ Diogenes Laertius II.40. This version is accepted as being most authoritative. 
entrap Anaxagoras in a suit designed to embarrass Pericles politically. The decree of Diopeithes was not referred to at the trial and is believed to have been voided by the Amnesty. Technically, Socrates was charged with nonconformity $x$ in religious practice, not for his beliefs. It was up to the prosecution to persuade the jury that Socrates' behavior fell under the implied provisions of the law. In any event, a charge on the ground of "impiety" gave a "legal foothold to the suit" 8 and permitted the plaintiffs to blacken the reputation of the defendant with accusations designed to engage the prejudice of the jury.

The clause in the indictment dealing with the introduction of new divinities has resulted in a division of opinion. On the evidence of the Euthyphro (3b) and Memorabilia (I.i.3.) some think it refers to Socrates' divine sign, described in the Apology (3ld) as "a sort of voice which comes to me, and when it comes it always dissuades me from what I am proposing to do, and never urges me on." But those who believe this is what is meant by the indictment have difficulty in explaining why the sign was thought to be in violation of the law. Dyer, for one, offers no explanation. 9

${ }^{8}$ Louis Dyer (ed.), and Thomas Day Seymour (rev.), Plato, Apology of Socrates and Crito (Ios Angeles: Demetrius \& Victor, Booksellers, 1973). pp. 24-25.

${ }^{9}$ Ibid., p. 24. 
Finley, on the otherhand, makes it appear that the introduction of new divinities was commonly accepted in Athens, but the choice of his examples, Asclepius, Bendidia and the Phrygian Cybele, is unfortunate. Their arrivals coincided with the start of the Peloponnesian War and the plague that ravaged Athens in 430-29. The importation of Asclepius, the god of health, was an obvious move; the Bendidia from Thrace was imported as a gesture of diplomacy to a nation of strategic military and economic importance; lastly, the Phrygian Cybele was introduced in atonement for the slaying of one of her priests, whose death was thought to have provoked the god into sending the plague. ${ }^{10}$ These examples are hardly on a par with the private sign of Socrates. Taylor, following Burnet, denies that the sign is what is meant by the indictment. Rather he conjectures the new divinities were most probably the non-religious substances of Ionian Science, those referred to by Aristophanes in the Clouds: ${ }^{11}$

Socrates: You do further engage to believe in no god save only our trinity--Chaos, Clouds, Tongue? ...

${ }^{10}$ Finley, op. cit., p. 65-6. For the introduction of Asclepius and the Bendidia see H. W. Parke, Festivals of the Athenians (Ithaca, New York: Cornell University Press, 1977), pp. 125 and 149. Information on the Phrygian Cybele was obtained from the oxford Companion to Classical Literature, Sir Paul Harvey, editor, 1969 edition.

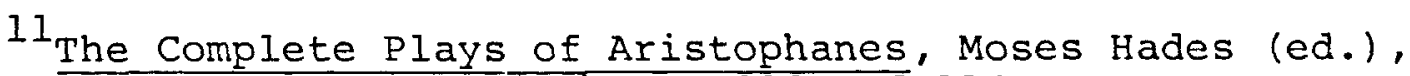
(New York: Bantam Books, 1971), pp. 112 and 114. 
They alone are deities, all the others nonsense.

Strepsiades: But on olympus ... is he no god?

Socrates: What zeus? Don't be silly; there is no zeus.

It is safe to conclude, however, that in spite of this difference of opinion, no one seriously believes that the introduction of new divinities by itself would have provided sufficient ground for conviction; but taken with the first clause, it further identifies Socrates with the irreligion of sophistical teaching and strengthens the indictment.

Taylor conjectures that the charge relating to socrates' refusal to recognize the gods of the state may have been intended by the prosecution to revive in the minds of the jurors the double sacrilege of 415; which, because of the Amnesty, could not be explicitly mentioned, but its recollection would have told against sacrates because so many of his friends had been implicated in the affair. Me-letus, as a member of the Eumolpidae priesthood, would especially begrudge Socrates' association with the notorious Alcibiades, whose recall from exile in 411 had been vigorously opposed by the Eumolpidae. Taylor further speculates that some of the jurors were probably aware that certain Pythagorean associates of Socrates were from cities that had opposed Athens during the recently concluded Peloponnesian War. ${ }^{12}$ One can hardly see why this would be a serious mat${ }^{12}$ Taylor, op. cit., p. 110 . 
ter. Cebes and Simmias, for instance, whom Guthrie identifies as "disciples of the Pythagorean Philolaus," 13 were both close to Socrates. They were from Thebes, a staunch enemy during the war; but also a city of refuge for the fleeing exiles, Anytus among them, who escaped the oligarchic tyranny. The theme of the Pythagorean menace is elaborated on by Burnet, who of Anytus says, "he doubtless knew that the followers of Pythagoras had been expelled from southern Italy just because they had tried to set up an international religion superior to any state..."14 This totally insupportable surmise fits in naturally with the view that Anytus undertook the prosecution in the interests of the restored democracy, to which the teachings of Pythagoreans and the sophists in general were inimical. The godless teachings of the Pythagoreans must also have awakened nightmares in the mind of Meletus.

The second count of the indictment--corruption of youth--is regarded as the more serious of the two charges by the political motive theorists because it was under this heading that Xenophon introduced the political accusations of Polycrates. Foremost among them is the accusation that Socrates had educated Alcibiades and Critias. This idea was

13 W. K. C. Guthrie, Socrates (Cambridge: Cambridge University Press, 1971), p. 169.

14 Burnet, op. cit., p. $105(24 \mathrm{cl})$. 
later echoed by Isocrates (XI.5), "When your purpose was to accuse Socrates ... you (Polycrates) gave Alcibiades to him as a pupil who, as far as anybody observed, never was taught by Socrates;" and Aeschines (I. 173), "You put Socrates the sophist to death, because he was shown to have educated Critias."15 Again, these charges could not have been raised in court by the prosecution, because of the injunction of the Amnesty; but it was believed that their political careers gave a good indication of the fruits of Socratic teaching.

The motives for the prosecution are unintelligible unless it is understood that Anytus honestly held Socrates and his teaching responsible for the mischief done to Athens by the man who had taught the enemy where to strike a deadly blow at her, and the man who had been the leader in the terror which followed her downfall.

Anytus, as leader of the restored democracy, acted in good faith in preferring charges against socrates, because he feared the Svengali who had created Alcibiades and Critias, if allowed to go unpunished, would create new monsters de-

${ }^{15}$ Pamphlet of Polycrates written ca. 393-2; Isocrates' 390-85; Aeschines' 350 .

${ }^{16}$ In so far as Alcibiades is concerned, Thucydides notes (XX.94) that the Spartans had, in fact, been considering the occupation of Decelea, which is what Taylor was referring to, before Alcibiades proposed it. It was more flattering to the Athenians to think that they had been defeated through the genius of one of their own. The spartans were a land army, the occupation of Decelea made good military sense from their point of view. Taylor, op. cit., p. 96, earlier had stacked the deck against Alcibiades by making it appear that he had been tried and condemned in absentia as a result of his advice to the spartans. But Thucydides (IXI.62) does not bear this out. For the quote in the text: Taylor, op. cit., p. 114 . 
structive to the state.

ADDITIONAL NOTE: VARIATIONS ON A THEME

The political motive theory, of course, has had its dissenters; but those who have endeavored to amend it--or overturn it-have still clung to the basic view of the individual prosecutors, which in one case has produced confusion, in another, a capitulation to the theory.

Guthrie, who would like to strike a middle ground between the political and religious issues suggested by the pamphlet and the Apology, respectively, creates a paradox of motives worthy of Zeno. His language is revealing:

(Anytus') objections to Socrates' behavior will have been largely political, but to bring political, charges against him, or mention his earlier association with Critias or Charmides, would have been contrary to the amnesty declared by the restored democracy, to which Anytus was conspicuously loyal. The accusation therefore confined itself to offences against the state religion and the vaguely worded "corruption of youth."

Thus he restates almost word for word the political motive theory outlined above. Surely the implication is that had there been no Amnesty Socrates would have been hauled up before the court on political charges-only the illegality of such action prevented him from being so. But after acknowledging the impediment of the Amnesty law, Guthrie shifts his ground, "The motive was in part political, but also wider, as Zeller has well expressed it (h. d. Gr. 217). Socrates, it is true, fell as a sacrifice to the democratic reaction which followed the overthrow 
of the Thirty; but his political views as such were not the primary motive of the attack on him. Rather his guilt was sought first of all in the undermining of the morality and religion of his country, of which the antidemocratic tendency of his teaching was partly no more than an indirect result, partly an isolated offshoot.

One has to remember the licentiousness and suspected sacrilege of Alcibiades, and the atheism of Critias, as well as their politics." 17 Guthrie wants to have it both ways. If the latter part of Zeller's statement is studied side by side with the indictment quoted above (Refer to p. 10 of this thesis), one can see how utterly uninformative it is-Socrates was indicted for the reasons stated in the indictment. In this Alice In Wonderland of logic, Anytus' large political motive has shrunk away to almost nothing, proving only to be a large part of something small.

Phillipson, whose encyclopedic study of the trial leaves virtually no stone, or motive, unturned--including the tannery stories that most everyone else rejects or ignores--in the end capitulates to politics:

Thus the ultimate attack on socrates in the law courts was intended partly as a vindication of orthodox or "unmixed" democracy as against the moderate party, which Socrates seemed to favour, and partly--indeed chiefly--as an impeachment of Socrates himself, because the settled democracy became certain that his peculiar and exceptional influence was a dangerously disturbing factor in the community. 18

${ }^{17}$ Guthrie, op. cit., pp. 61-3. Underscores are mine.

${ }^{18}$ Phillipson, op. cit., p. 211. For his account of Anytus' motives see p. $2 \overline{08 f}$. 
Phillipson's two-tiered summary is really a tautology: Socrates was tried on account of his political beliefs, or lack of them.

M. I. Finley's rejection of the political motive, "beyond its background role in the minds of some jurors," 19 does not go far enough, but it clearly points out some of the shortcomings of the theory. His observation that neither Plato nor Xenophon, both of whom opposed the democracy, mention the motive is, I think, telling. The VII Letter, attributed to Plato, where it is said that socrates was brought to trial not "for political reasons," but "by some chance"-me cites as a place other than, say, the Apology, where the true (political) motive might have been revealed, but was not. However, Finley neglects to rebut the evidence of the Meno, from which Burnet claims, "it cannot surely be doubted that Plato means us to understand that, in his view, the prosecution of Socrates by Anytus was due to his disparagement of democratic statesmen." 20 Nor does he address the issues raised by the pamphlet of polycrates. His opinion that a "chance combination of history and personal factors ... produced the great tragedy of 399," while it sounds good, is, of course, a broiler plate on which anything--

${ }^{19}$ Finley, op. cit., pp. $63-4$ and 70 . 20 Burnet, op. cit., p. 74 (18b3). 
large or small-- can be fried; it is a kind of zen explanation for all of life. But Finley is on the right track; the political theory is faulty for the reasons he suggests--and also for others. 
CHAPTER III

REFUTATION

The Identity of Meletus

Political theorists suggest that Meletus' religious ire was nurtured by the grudge his family, the Eumolpidae, bore Alcibiades, and for the latter's behavior he held Socrates anyhow responsible. This idea is based on the assumption that the Meletus who tried Socrates is the same who tried Andocides, for it was this Meletus who definitely sprang from the Eumolpidae clan and bore the grudge. If a wedge can be driven between the two, this part of the motive falls apart.

Burnet acknowledges but two weak links in the evidence:

There are only two objections of any weight to the identification of our Meletus with the Meletus who spoke against Andocides. In the first place, Andocides telis us (1.94) that the latter was one of those who arrested Leon of Salamis, and Socrates relates the story in the Apology without a hint that his accuser had anything to do with $\dot{t}$. That, I think, can be explained (Ap. 32d6n)."

${ }^{21}$ Burnet, op. cit., p. 9. 
This first objection will be examined before proceeding on to the second. His reference to the Apology is a passage where Socrates tells of his refusal to join in the arrest of Leon. He omits to mention that Meletus, presumably his accuser, had taken part in the arrest. Burnet notes, "it is doubtless strange at first glance that Socrates should not allude to his (Meletus') complicity in the arrest of Leon." Yes--if one insists on the identity, but how does he explain the omission? He asks us to consider the niceties of speechmaking:

But Meletus has been completely disposed of by this time, and it is much more effective to ignore him than to make a small personal point against him. The grave seriousness of this part of the speech would be impaired by anything of the kind. Socrates could not stoop to comparison 52 between his own conduct and that of a Meletus.

These statements shall be taken one at a time. By insisting that Meletus had been completely disposed of earlier in the Apology, Burnet is referring to Socrates' cross-examination of Meletus, where he traps the latter into accusing him of atheism, so he can point out how this fresh accusation contradicts the clause in the indictment that accuses him of having introduced new divinities: he cannot both believe in the gods and not believe in them (Apology, 27d). Whether this argument "completely disposed" of Meletus is certainly 
arguable. Taylor correctly observes that with this examination of Meletus, Socrates has evaded rebutting the charge that he is a maker of new gods. 23 True, a joke has been made at Meletus' expense, but the argument does not make an effective defense. Burnet seems to sense its ineffectiveness; later he notes that the end of the examination is "a puzzle at first sight" which only "works out ... if we take time to it." 24 What effect this puzzle of a conclusion had on the minds of the jurors, who had not the leisure to weigh its subtlety in the comfort of a booklined study, one can only guess at. Burnet is now in a position where he has to argue that some of the jurors were probably quick enough to have picked up on it. These are the same whom Bury has described as "the poor and idle, who found it pleasant to sit in court listening to curious cases..."25

In any event, it cannot be stated with confidence that this dialectical display had disposed of Meletus, completely or otherwise.

Burnet's assertion that mention of Meletus' participation in the arrest of Leon of Salamis was but "a small personal point" against him is another matter. Juxtaposed to

$$
\begin{aligned}
& 23 \text { Taylor, op. cit., p. 108-9. } \\
& 24 \text { Ibid., p. } 116 . \\
& 25 \mathrm{~J} . \text { B. Bury, and R. Meiggs, A History of Greece, }
\end{aligned}
$$
Fourth Edition (New York: St. Martin's Press, 1975), p. 349. 
the statement that socrates "behavior in the affair... was the strongest point in his defense" and therefore "he was entitled to make the most of it," it can be seen here that a double-standard is being applied. To repeat: Meletus' compliance is a small personal point against him; Socrates' refusal is the strongest point in his defense. A consistent standard is missing. Moreover, it is difficult to see how the gravity of Socrates' refusal outweights the seriousness of Meletus' complicity in the affair. Socrates' failure to mention the latter seems to contradict the claim that he was entitled to make the most out of the episode. Contrasting his behavior with that of his accuser's would have accomplished this. The assertion that reference to Meletus at this point would have been rhetorically improper is not fully explained. If it was indeed the strongest point in Socrates' defense, what was to prevent him from raising it elsewhere. Andocides had found a place for it in his defense and he had nothing to do with the episode. Last of all, the comment that socrates would not "stoop" to comparisons between himself and his accuser is not borne out by other passages in the Apology (25d9 and 34a2) where Socrates appears only too happy to show himself the better man. According to the criteria Burnet employs to measure the weight of the affair, one can only conclude that the omission of Meletus' complicity indicates that it was not he who arrested Leon, but the Meletus who prosecuted 
Andocides. 26

The second and only other objection Burnet sees to the identification is most bizarre.

In the second place, Andocides (II.150) is able to call Anytus to speak in his favour; but that was no doubt because the accusation was a flagrant violation of the Amnesty, to which Anytus was conspicuous loyal. 27

At first sight, it is not clear why Burnet should see this as an objection; if it is, it is a weak one. Surely Meletus and Anytus could have agreed to the issues involved in the case of Socrates and disagreed over those pertaining to Andocides. Consistency does not require that the two should be on the same side in every case. Then why does Burnet assume that it does?

First of all, it must be recognized that the second objection does not address directly the issue of identity at all. It only points out that Anytus supported the prosecution of Socrates and spoke against that of Andocides. This information would be significant only if one had already proved that the Meletus in each case was the same; there

26 When he speaks of "a Meletus" Burnet seems to be recalling an earlier remark that if the two Meletuses were not the same then "there were two like-minded persons called Meletus who came forward as champions of religion in the same year," p. 10 (2b9). So it doesn't matter which Meletus, they were both alike anyway. As to the remark that the name was uncommon, there was one in Andocides II 12; another in Hellenica II.iv.37; and the two above.

27 Burnet, loc., sit., p. 9. 
would be no sense in contrasting Anytus' behavior with that of two different men. In order to answer this second objection to the identity of Meletus, Burnet has had to assume that it is true. One need only rephrase the objection to reveal its absurdity: Anytus' support of Andocides proves the Meletus who spoke against Andocides is the same Meletus who prosecuted Socrates. Clearly the second objection has nothing to do with the question of identity. Its purpose is to insinuate that the two trials are equatable; and if the two trials are equatable, then (possibly?) Meletus = Meletus. 28

Then, according to Burnet, there is only one objection of any weight to the identity of Meletus--and that one told against it. But the arrest of Leon poses other problems to the identity. After being given the arrest order, Socrates, in the Apology explains what happened next, "when we came out of the rotunda the other four went to salamis and fetched Leon, but I went quietly home." (32d) So we have Meletus, the supposed prosecutor of Socrates, and Socrates together in the rotunda receiving the same order with three other men. Yet, four years later Socrates claims to have never heard of him (Euthyphro 2b). Socrates' memory lapse has to be

28 Ibid., p. 137 (32d6) where Burnet admits the first objection "is the only serious reason for doubting the identity...." One is therefore left with the assumption that he meant the second one as a jest. 
accounted for, or the identity dropped.

The chronology of the two trials poses more difficulties. For a long time it was believed that the trial of Socrates took place in the Athenian month of Munychion (midApril-mid-May). This was inferred from the fact that the annual mission to Delos departed the day after the trial, which delayed the execution. Plutarch (Theseus 24) affixes the sixth of Munychion as the date of departure. Zeller, correcting this view, assigns the departure to an earlier month, Anthesterion (February-March). 29 In either case, as the Athenian new year began with the summer solstice, Socrates' trial had to occur in the latter part of 400-399. The trial of Andocides, also in 400-399, appears to have resulted from an incident which occurred during the celebration of the Eleusian Mysteries (Andocides II.121), which was held during the month of Boedromion (September-October). According to the evidence inherent in the sources, the trial of Andocides fell early in the year of 400-399 and therefore preceded that of Socrates'. With the exception of Bury, with whom we'll deal $b$ e 1 . O. w, most scholars accept this chonology, if they commit themselves at all. 30

${ }^{29}$ Eduard Zeller, Outline of the History of Greek Philosophy, Thirteenth Edition, (London: Routledge \& Kegan Paul, Ltd., 1969), p. 97ni.

${ }^{30}$ A. N. W. Saunders, (trans.), Greek Political Oratory (Baltimore: Penguin B o oks, 1970), p. 97; and James Beckman, The Religious Dimension of Socrates' Thought (Ontario: Wilfrid Laurier University Press, 1979), p. 104n43, accept the above chronology. 
Burnet and Taylor, characteristically, keep the issue vague, which works to their advantage; but establishing a chronology is important for a number of reasons.

First of all, Andocides in minute detail rehashed "the old scandal" of 415 , in which many of socrates' friends had been implicated. Certainly socrates would have taken an interest in the proceedings, or have had some information concerning them. If Meletus was the wild-eyed religious fanatic Burnet and others make him out to be, surely he would have achieved some notoriety on the basis of the speech, reputed to be his, that survives in the works of Lysias (VI). But several months later socrates can claim he has never heard of his accuser.

His Association with Anytus

This chronology also raises the question of why, especially since he lost the case, Anytus should have tapped Meletus to lead the suit against Socrates. Anytus is described as a prominent man, shrewed, honest, with no unworthy motives. Was this the best he could do? Did others turn him down? If "the ancient Greeks took religion seriously," 31 surely others more capable than Meletus shared Anytus' views concerning Socrates. Why not someone else-unless, of course, he did select someone else.

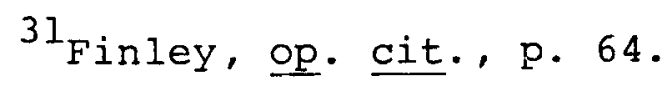


This strange union has troubled those who maintain the identity. It is usually lamented in the following fashion:

It is less creditable to Anytus that, in order to get rid of Socrates, he stooped to make us of the fanaticism of Meletus (whom he must have despised, adds Taylor 32 ).

It was doubtless due to his influence that the latter's indicţment was couched in such vague and obscure terms.

What is one to imagine then? Anytus saw Meletus' fanatical tirade against Andocides and thought, Here's the man to prosecute my case against socrates. Or did he muse, If someone had only put a tight rein on Meletus, he would have won the case. Or was it this: If that boy had only obscured the terms of the indictment against Andocides, made them more general, so as not to blatantly breach the Amnesty law, and argued them vaguely in court--he would have nailed him. Any of these scenarios borders on farce, unless we suppose that Anytus' partner in the prosecution of Socrates was another Meletus.

Confusion reigns as to who bore the responsibility for what. In an attempt to remove Anytus from the taint of his association with Meletus, Burnet hints in one place that Anytus was probably only responsible for the political half

32 Taylor, op. cit., p. 104.

33 Burnet, op. cit., p. 101 . 
of the indictment. 34 Bury, on the other hand, an advocate

of the political theory, states that Anytus

decided that the best ground of attacking Socrates successfully would be 'irreligion'; it was common knowledge that the philosopher was far from orthodox. Accordingly an arrangement was made with a minor poet named Meletus, who was a fanatical champion of religion, that he should bringagainst Socrates a public suit for irreligion..." 35

According to Bury, Anytus picked the charge and then the man to present it.

As stated above, he positions the trial of Andocides after that of Socrates. On the strength of this sequence, it could be claimed, by those who want to save the reputation of Anytus, that to him Meletus was an unknown quantity. Something of the sort seems suggested by Chroust, who remarks,

Meletus was not altogether successful in his efforts at substantiating the allegations made in the official indictment. For one moment it appeared that socrates would be acquitted. Then Anytus stȩ̧s in to save the situation for the proscecution.

Perhaps Anytus was unaware of the true extent of Meletus' fanaticism, and did not realize what a bad bargain he had struck until it was too late. Having Andocides follow Soc-

${ }^{34}$ Ibid., p. 151 (36a8).

${ }^{35}$ Cambridge Ancient History, Vol. 5, XII, viii, p. 391.

${ }^{36}$ Chroust, op. cit., p. 171. 
rates would also allow for Socrates' claim to have never heard of Meletus. T'his, at last, seems a workable timetable; but, in order to make sense of the theory, it has been necessary to reverse the actual sequence. Once again, if the insistence on the identity is discarded, juggling the chronology would not be necessary.

Anytus' selection of Andocides' Meletus faces another problem that turns on his participation in the arrest of Leon. From Letter VII $(325 \mathrm{c})$ it can be argued that Anytus was a friend of Leon. The writer relates that, in condemning Socrates, they executed "the very man who had refused to have any hand in arresting one of their own friends when they themselves were in exile and misfortune."37 "They" applies to (Anytus and) the democrats. Another link is provided by his association with Theramenes (Ath. Con. 34.3), who in the Hellenica (II.iii.39) expresses the opinion that the arrest and execution of Leon was unwarranted and describes the Salamian as "a man of capacity, both actually and by repute." Assuming Anytus, too, shared in this view, it is indeed odd that he should later choose to team up with one of Leon's executioners--according to the law, anyone engaged in the arrest of a man put to death without a trial was liable for homicide (Andocides II.94)-in a suit demanding the death penalty against a man who had

${ }^{37}$ Guthrie translation, op. cit., p. 61 
refused to participate in the arrest. Furthermore, if--as Burnet and others believe--one of the things held against Socrates by Anytus and the democrats was the fact that he had remained in the city during the revolution, and had not aided the exiles in their fight to bring down the Thirty, why did Anytus not feel the same resentment toward Meletus? According to Andocides, Meletus would have been tried for homicide by the relatives of Leon, if the Amnesty had not been declared. It appears that he, like Socrates, had remained in the city during the course of the fighting, and yet none of this is counted against him. In fact, if Anytus picked the Meletus of Andocides he could not have decided on a stranger bedfellow: a man of the city and an accomplice to his friend's execution.

The Meletus who arrested Leon could very well be the Meletus who served as the city's envoy in early negotiations with the party of exiles at Piraeus (Hellenica II.iv.37). It is not likely that the envoy was a young man barely out of his teens, nor does it seem likely that he would be the nonentity chosen by Anytus to prosecute Socrates; but he could very well have been the man who arrested Leon.

There are, then, a great many more objections to the identity than the one and a half proposed by Burnet. The question must then be asked: Why would anyone push for this identity in the face of all the above difficulties? Part of the reason for this has already been suggested--the prosecu- 
tion must be made to appear worthy of the political motive. Superficially, the Meletus of Andocides, with his known tie to the Eumolpidae priesthood and their feud with Alcibiades, seemed to link both politics and religion together. He served as a lightening-rod for those two issues. He also served one other very important function.

Those who advocate the political motive seem to think the future of democracy in Athens was the central issue at stake in the trial. The intellectual power and influence of Socrates is opposed by the political power and influence of Anytus--two eminently worthy contestants. But some are more worthy than others and the issue was decided against socrates. Who was to blame? Meletus, the religious fanatic, made an ideal whipping-boy. Here was a young punk bringing up a charge of atheism against a man perceived by some as a "prophet" of Christianity. ${ }^{38}$ Moreover, Meletus had neither wealth nor distinction to speak in his favor, as Anytus did. Lacking someone to blame, the little guy gets picked on. Meletus provided an easy target and became the scapegoat. By contrast Anytus was made to appear even better.

$38_{\text {Tredennick, op. cit., p. 9. F. M. Cornford, Before }}$ And After Socrates (Cambridge: at the University Press, 1966), p. 53. Taylor, op. cit., p. 132f, credits socrates with the discovery of the concept of "soul." 


\section{Anytus}

How the character of Andocides' Meletus warps modern accounts of the trial can be seen in Taylor's portrayal of Anytus. "Anytus, son of Anthemion, the instigator of the proceedings, seems to have had no unworthy motive, nor was he a political or religious fanatic." 39 First of all, it should be said that fanaticism is probably the last thing one would expect of anyone, but here it is mentioned first. (How totally unworkable it is as a descriptive tool will become apparent later.) Secondly, Taylor has yet to introduce Meletus; his character is to be used for a study in contrast, to focus Anytus in the best light possible. He goes on to justify the litotes of the introduction.

In politics he was a moderate democrat and a chief promoter of the amnesty between the conflicting factions after the downfall of the "Thirty," proving his loyalty to it by refusal to seek any compensation for grave personal losses under the usurpation.

Later he refers to Anytus as "a prominent moderate politician." 40 This is the standard assessment of Anytus. The descriptive terms seldom vary; but if the slender evidence on which they are based is critically examined, what appears

$39^{\text {Taylor, } \text { op. }}$ cit., p. 102

40 Ibid., p. 103. Taylor seems to contradict the statement that Anytus was "a moderate democrat" on page 99, where he says the Thirty "forced the more radical democrats to leave the city." Anytus was one of these. 
is--as Voltaire said of the Holy Roman Empire, that it is neither holy, nor Roman, nor an empire--that Anytus was neither prominent, nor moderate, nor a democrat:

\section{His Prominence}

It may seem foolhardy to deny that Anytus was prominent. Both Plato (Meno 90) and Xenophon (Apology 29) testtify that he was a high government official. The speaker in Isocrates XVIII (23) refers to him as one of two "men with the greatest influence in the city." We know that he was a general during the Decelean phase of the Peloponnesian War (Diodoros XIII.64.6) and again served in that capacity as leader of the exile army that toppled the Thirty in 403 (Hellenica II.iii.44; Lysias XIII.78). None of this will be denied; but a curious thing happens when one ruminates over the evidence of his prominence, there is--other than the above--little more to be found.

To begin with, Thucydides overlooks him completely in history of the Peloponnesian War. Xenophon, who took over the history, describing events through the civil war of 4043 and beyond, refers to him but twice, and indirectly, the references coming in a speech put in the mouth of Theramenes. Diodorus, another historian of the period, tells of his appointment as general in 409, a fact confirmed by Aristotle (Ath. Con. 27.5). Both relate this information only because the outcome of the event to which it was related established a historical first. Having failed his assignment, Anytus 
was indicted for treason and escaped conviction by bribing the jury. He was the first known to have done so. Had it not been for this, there would be no record of his having served in the war at all. Of his role as the leader of the exiles, of the restored democracy, Diodorus says nothing. $\mathrm{He}$ is not credited with leading assaults, devising strategies or rousing his men into action--as Thrasybulus is. Aristotle mentions him in a group headed by Theramenes, but while each of the others is credited with forwarding a piece legislation, Anytus has none. 41 And this is the man Burnet describes as "one of the authors and leading supporters of the Amnesty." 42 Why wasn't Aristotle able to make this claim--if it was true. He credits the Spartan king Pausanias and Rhinon for the peace which followed the downfall of the tyrants (Ath. Con. 38.4). The conspiracy of silence is extraordinary: the poets, the dramatists, the orators, the historians--stoney silence--a curious kind of prominence, indeed, for a man for whom so much is claimed. The anomaly presented by the sources seems to suggest that Anytus operated--if anywhere--behind the scenes, a man of wealth and influence for whom others did the bidding; his was the

41 Ath. Con. 34.3. Archinus 40; Cleitophon 29.3; Phormisius (Lysias XXXIV see Introduction by Lamb); Theramenes 28.5 .

${ }^{42}$ Burnet, op. cit., p. 101. 
anonymity of the power-broker--the prominent low-profile.

As a Moderate Democrat

"Moderate," of course, is meant by Taylor to qualify democrat. But the term is used so loosely that it is not often clear whether it is meant to refer to his politics or temperament. Furthermore, what is cited as evidence of moderation can often be turned around to prove the opposite. Following the Athenian defeat at Aegospotami, which effectively ended the war with sparta, three political factions, according to Aristotle (Ath. Con. 34.3), manuevered for control of the city: the democratic party formerly headed by Cleophon; the extreme oligarchs headed by Critias and Charmides who, with Lysander's connivance, eventually acceded to control; and a group somewhere in between which was in favor of imposing certain limitations on the democracy. This was the faction to which Anytus belonged--headed by Theramenes. It was perhaps on the strength of Anytus' inclusion in this group that Burnet was able to conclude that Anytus was "not an extreme democrat." 43 But, as with the half cup of coffee--is it half full or half empty?--this middle ground, in the absence of any sure knowledge, is difficult to get a handle on. von Fritz and Kapp call it "the 
moderately conservative party," and "the moderate wing of the anti-democratic party." 44 which is it, moderate democracy or moderate oligarchy? Indeed, it is appropriate that its natural leader should be Theramenes, called the "buskin," for the Greek sandal that would fit either foot.

Noticeably absent from Aristotle's post-war inventory is the name of Thrasybulus--with whom Anytus is often Iinked as a fellow exile and co-leader of the counter-revolution and democratic settlement. Where would he fit in among the three conflicting factions? Taylor relates that the "oligarchial revolutionary government ... forced the more radical democrats to leave the city;" Xenophon has Theramenes mention him (and Anytus) in the same breath as Alcibiades (notoriously popular with the commons) 45 as among those banished by the oligarchs (Hellenica II.iii.42). Does this mean he was on the left, one of the extreme democrats? His banishment occurred early in the reign of the Thirty, which would indicate extremism of a kind; though it could also mean that, like others, he was driven out less on account of his politics than his wealth, as Lysias XII (7) indicates was frequently the motive for banishment. The pairing of

44 Kurt von Fritz and Ernst Kapp (trans.), Aristotle, Constitution of Athens \& Related Texts (New York: Hafner Press, 1950), pp. 60 and $98 \mathrm{nb}$.

${ }^{45}$ Plutarch, Alcibiades 36. 
Thrasybulus and Anytus, and the timing of their exile, would suggest something other than moderation; for when the democracy, which they headed, was later restored, the constitutional reforms favored by Theramenes were never enacted (Ath. Con. 41.1$)$.

How difficult it is to fix one's politics on the basis of whom one is said to have been associated with is pinpointed by a dispute which arose shortly after the democracy was restored. Thrasybulus proposed a decree that citizenship be extended to all those who had fought on the side of the Piraeus party. This proposal was successfully challenged by Archinus on the charge of unconstitutionality (Ath. Con. 40.2). Also defeated on the same charge, was another proposal, introduced by Phormisius, limiting citizenship only to those who possessed land (Lysias XXXIV). Both Archinus and Phormisius are listed by Aristotle, with Anytus, as belonging to the faction headed by Theramenes. Phormisius' proposal reflects oligarchical tendencies; Thrasybulus', on the other hand, suggests extreme democracy --for his decree would have granted citizenship to slaves. Who represented Anytus' stand on the issue? Where did his sympathies lie? He was a leader, was he not?

The timing of Anytus' exile--whether it was immediate. or occurred sometime during the reign of terror imposed by the Thirty--could conceivably shed light on the question of his politics, if the sources were more clear. Theramenes, 
in the Hellenica speech, has him in exile with Thrasybulus. It has been supposed that they were targetted for exile by the Thirty on account of their wealth. The evidence of Lysias XII for this has already been cited. Diodorus mentions wealthy citizens, along with resident aliens (metics), were being murdered daily in order for the revolutionary government, which was hard pressed for money, to gain control of their property: once the slaughter became indiscriminate, he adds, the "well-to-do ... fled from the city almost to a man" (XIV.5.6). Isocrates XVIII (23) tells us that both Anytus and Thrasybulus were "robbed of large sums of money" while in exile. What the account of Diodorus suggests is that Anytus' exile may have waited until after the death of Theramenes when the violence became general. This account would contradict the chronology of Xenophon's, as implied by the speech of Theramenes. Anytus' official banishment, at any rate, would have been imposed in abstentia (Hellenica II.iii.42). Of course, this discussion has little to do with politics. The oligarchs, who ruled as the Thirty, were not the wealthy class they are often mistaken for; 46 "the

${ }^{46}$ I. F. Stone, for one, while noting "executions for revenue purposes were common under Critias" nevertheless falls back on the knee-jerk assumption that all oligarchs were rich when he describes the Thirty as "the dictatorship of the wealthy landed aristocracy" without making note of the fact that their lands had been ravaged the last seven years of the war and their vealth wasted fighting it. I. F. Stone, "The Socrates Story," The New York Times Magazine, April 8, 1979, p. $23 f$. 
State was impoverished, and the government needed funds," Lysias tells us (XII.6-7). The war had reduced the landed aristocracy to penury. Considering the small number of exiles (Xenophon puts their number at 70, (Hellenica II.iv.2)) marshalled at Phyle by Thrasybulus, there were few wealthy --democrats or oligarchs--Athenians remaining. It is quite possible those who had at one time supported the reforms of Theramenes, after undergoing financial persecution, had experienced a political conversion in exile and returned to the city reborn as democrats.

The absence of political principle would explain Anytus' affiliation with Theramenes and his later apostasy. At the time of his return the latter would have been smart politics. The speaker in Lysias XII (62-78) blames Theramenes for the negotiated peace with sparta that turned the government over to the oligarchs; he claims that Theramenes himself was responsible for the recall of the exiles, like Critias, who turned the oligarchy into a reign of terror, and for the role he played in the oligarchic revolution of 411. The speaker, of course, was a democrat speaking before a jury of democrats in 403 . Theramenes was a "buskin" even in death. Aristotle, tutor to a crown prince, applauded him for his life-long efforts to bring the excesses of democracy under control (Ath. Con. 28.5). As a man of means, it was perhaps prudence which counselled Anytus upon his return to steer clear of the moderately conservative policies cham- 
pioned by Theramenes. At any rate, his low visibility during this period suggests the movements of a prudent, pragmatic man who cared more for his life and livelihood than political principle.

Moderate-extreme are used in another way that has little to do with politics. Citing Letter VII, Guthrie says of the democrats, "These were not men of violence like the Thirty, Plato himself, who had every reason for disliking them, pays tribute to the moderation with which they conducted themselves after their restoration." 47 This only indicates that the treatment accorded the defeated oligarchs was moderate by contrast to the vindictive reign of terror which was the hallmark of their administration. It does not mean that the democrats founded a new government based on the constitutional reforms proposed by Theramenes and "the moderate wing of the antidemocratic party." The democracy which, after the war, was thought so extreme; following the revolutionary terror, seemed so no longer. Perhaps as a concession to the image acquired during the tenure of Cleophon, the democrats, with the war removed, renounced a program of reprisal and accepted the Amnesty.

Moderate, then, has been used in a dual capacity--to denote a middle position on the political spectrum and to

${ }^{47}$ Guthrie, op. cit. , p. 61 
refer to the conduct of the democrats following their restoration. Both senses have been loosely applied to Anytus. It is not clear whether he was in his politics extreme or moderate. The oligarchs seemed to think he was extreme--or extremely wealthy--and banished him. He belonged to the moderate party of Theramenes. The democrats perceived the latter as an oligarch. Anytus emerged later as a leader of the democracy. The relativity of the sense can best be illustrated if Taylor's description is recalled of Anytus as "a moderate democrat," and Phillipson's conclusion that "the ultimate attack on socrates in the law courts was intended partly as a vindication of orthodox or 'unmixed' democracy as against the moderate party, which Socrates seemed to favour..."48 This last party, of course, was the party Aristotle had Anytus belonging to prior to the revolution of 404-3. Curiously, we now have Anytus and Socrates sharing the same political agenda, and yet Anytus is said to have tried Socrates because of his politics. Well, if Socrates was moderate, then Anytus was extreme; conversely, if Anytus was moderate, then Socrates was extreme. We seem back at the question of the cup of coffee: is it half empty of half full? The sharp dichotomy of democrat-oligarch dissolves to grey in the middle ground.

The broad brush which paints Anytus with the modera-

${ }^{48}$ Phillipson, op. cit., p. 211 . 
tion of the post-revolutionary democracy tends to gloss over the details that stand in the way. One of which is the apparent haste with which Anytus, on his return, proceeded with the prosecution of Socrates. Libanius, noting that four years separated the two events, charged "Anytus with serious dereliction of duty for having failed to proceed against Socrates sooner." 49 Rising to the defense of Anytus, scholars have responded with a prima facie case for the view that Anytus took swift action against Socrates.

It has been asked why the prosecution was delayed .... The explanation is that the revolution and counter-revolution of $404 / 3$ had brought the ordinary work of the law-courts into confusion; the whole body of Attic law had to be revised and codified, and the Commission appointed for the work did not finish its task until the year $401 /$ 400. This is why the proceedings against Socrates could not be set on foot until 400; in point of fact, Anytus made 50 is move as soon as it was really practicable.

It is not known, of course, whether the above applies to the case of Socrates. Isocrates XVII; XXI and Lysias XII are evidence that trials did occur during this period. Moreover, in Lysias XIII, a trial which occurred in the same year as Socrates', the defendant is charged with crimes committed under the Thirty; but his accuser, although he mentions the long delay between the commission of the crime and the

${ }^{49}$ Chroust, op. cit., p. 259 n. 460. ${ }^{50}$ Taylor, op. cit., p. 103. 
indictment, fails to cite the confusion in the law-courts as the cause of the delay, when it would have been to his advantage to do so (83). However, assuming the confusion in the courts delayed the prosecution of socrates, the explanation quoted above clearly implies that, had there been no legal impediment, Anytus would have initiated the proceedings in 403, in other words, "as soon as it was really practicable." While the swiftness of his reaction hardly seems worthy of labelling as that of a "political fanatic," it clearly tells against a case for moderation.

The importance of hypothetically moving the trial closer to the period $404-3$ is theoretical: it gets Socrates closer to the crimes the political theorists allege he is on trial for. From the moment the exiles entered the city in 403, Chroust, it should be remembered, believed Socrates was "hopelessly doomed." 51

Winspear and Silverberg employ the umbrella of Letter VII as proof of Anytus' moderation, and then over it throw the following awning: "As a matter of fact, the democracy was almost incredibly tolerant toward the men who attempted to destroy it." 52 Perhaps Winspear and Silverberg took into

${ }^{51}$ Quoted on page one. Burnet seems unclear whether Socrates was being tried for crimes commited before 403 (op. cit., p. 100) or after (p. 105), in which case the discussion of the Amnesty and the legal revision would be irrelevant.

$52 \mathrm{~A}$. D. Winspear and T. Silverberg, Who Was Socrates? (New York: The Cordon Company, 1939), p. $\overline{72 .}$ 
consideration the evidence to the contrary: the lawsuits: Lysias VI, XII, XIII, XVI, XXIII, XXV, XXXI; Isocrates XVIII, Xx; the knights who "volunteered" to serve with Thibron, because "the Athenians (thought) it would be a gain to the democracy if they should live in foreign lands and perish there" (Hellenica III.i.5); the treacherous butchery of the leaders of the Thirty two years after they had been solemnly guaranteed the sanctuary of Eleusis under the sworn covenants of the Amnesty (Hellenica II.iv.43); and, the trial of Socrates. It is apparent now why winspear and Silverberg used the qualifier "almost;" the democracy was only credibly tolerant after all. Their effort to make the democracy appear better than it was is a smokescreen to conceal the paltry evidence and specious arguments made in favor of Anytus. In all consistency, the latter must be credited with the worts as well as the beauty-marks.

The conduct of the democrats was moderate in contrast to the terror of the Thirty: the conduct of Anytus was moderate in contrast to the fanaticism of Meletus. A like pattern of argument is employed to defuse the prosecution's demand for the death penalty. The spector of capital punishment was a tactical terror, conjured up to frighten socrates into fleeing the city--exile, that was all that was intended. "One need not accuse Anytus and his associates of 
thirsting for Socrates' blood." 53 The gory hyperbole is hardly apropos considering the means of execution was a draught of poison without any violent side-effects, but it makes the explanation which turns the penalty on its head appear more reasonable than it is. Explained in this way, exile seems like a bed of roses--compared to death. But it was hardly that. To a Greek it was filled with tragic consequences: Oedipus' suffering was banishment; Odysseus' adventures were obstacles to his homecoming. The latter part of Alcibiades' life was devoted to manipulating a balance of power that would effect in his recall to Athens. Anytus, himself, returned to the city at the head of an army. Rather than brave exile, Socrates chose death. If Anytus and his minions had proposed exile with the intention of settling for the payment of a stiff fine--that would have been one thing. But they did quite another. To imply that what they intended was a moderate penalty for a man in his seventies to pay is a gross distortion of fact.

${ }^{53}$ Guthrie, op. cit., p. 63. Probably an echo of "nor had he (Anytus) any desire to shed blood," Taylor, op. cit., p. 102 . 


\section{As Chief Promoter of the Amnesty}

What Taylor and others have in mind, however, when when they speak of Anytus' moderation is his presumed status as a chief promoter of the Amnesty. This claim is inferred from a solitary passage in Isocrates XVIII (23) that also includes a report of the financial losses sustained by Anytus while in exile. Out of this passage the unwieldly motif of moderation was evolved.

Thrasbulus and Anytus, men of the greatest influence in the city, although they have been robbed of large sums of money and know who gave in lists of their goods, nevertheless are not so brazen as to bring up old grudges against them; on the contrary, even if, in respect to all other claims, they have greater power than others to accomplish their ends, yet in matters covered by the covenant at least they see fit to put themselves on terms of equality with the other citizens. And it is not these men alone who have accepted this point of view; no, not even one of you has dared to bring such an action.

This last sentence is invariably excluded when this passage is cited--and with good reason. What it seems to indicate is that Anytus' "loyalty" to the Amnesty--his moderation-was not so very remarkable afterall. The speaker himself does not boost Anytus as one of the chief promoters of the Amnesty; that has only been an inference, and a faulty one at that:

Anytos had the power to violate the Amnesty. Whoever has the power to violate the Amnesty and does not, promotes it. Anytus did not violate the Amnesty. Therefore: he promotes it. 
But the passage does not support this conclusion, it only says that Anytus was not "so brazen as to bring suit" in violation of the Amnesty. A story related by Aristotle may explain why (Ath. Con. 40):

When one of those who had participated in the return began to take up complaints in violation of the Amnesty, Archinus took him before the Council and persuaded the councilmen to have him executed without trial. He achieved this by telling them that now was the moment when they must show whether they were willing to save the democracy and to live up to their oaths. For if they were going to let this man off, they would encourage others to act as he did; but if they executed him, they would set a warning example. This was actually the result. For when he had him executed, nobody dared to violate the Amnesty again. 54

The similarity in the two passages, at one point, is quite remarkable. Aristotle claims, "nobody ever dared to violate the Amnesty" and the speaker in Isocrates says, "not one of you has dared to bring such an action." Together what they seem to suggest is that most everyone complied with the terms of the Amnesty; exceptions were rare. Those who see the remarks in Isocrates as evidence of moderation on Anytus' behalf rely on the supposition that he could have broken the law (and got away with it) and did not. It is either one way or another; he either violates the Amnesty or promotes it; breaks the law or makes it. The strange consequence of this line of reasoning is that in order to fit everything Isocrates XVIII are at least two examples to the contrary. 
into the theme of moderation, no allowance is made for the middle ground.

There is, incidently, reason to believe the client of Isocrates was overstating the power of Anytus in order to heighten his point. Remember the adjurations of Archinus before the Council (perhaps Anytus was among their number): had Anytus the power attributed to him and exercised it, thereby breaking the Amnesty, would he not have cemented the way for others to follow suit--just as Archinus had warned. Furthermore, whatever his official position, he was required by law to submit to a public inquiry prior to taking office and at the end of each term. These inquiries had a legal aspect and could at times be quite thoroughgoing. 55 Whatever his public standing before entering office, there was always the danger that if he exceeded his legal authority he would be subject to criminal indictment. His actions were circumscribed by law enforced by public opinion. Athens was a democracy; the people were accustomed to rule. Unless one is prepared to assume that at one moment he held the power of a dictator, like Critias before him, and could have gone one way but went another, it is idle to think of his obedience to the law as something out of the ordinary. He obeyed the law like everyone else. Besides, one might

${ }^{55}$ Gustave Glotz, The Greek City (New York: Barnes \& Noble, Inc., 1969), p. 219. 
just as well suppose he was in court the day the above speech was delivered and the speaker meant to flatter him. Or that the passage was a piece of rhetoric meant to appeal to the democratic sensibilities of the jurors. As a fact, it can betaken with nothing more than a grain of salt.

Anytus' apparent unwillingness to seek restitution of his stolen property is interpreted as unquestionable evidence of his committment to the Amnesty. It is as though the depth of his investment is measured by the extent of his losses. He is a promoter in a financial sense as well as the sense that he was directly responsible for bringing the Amnesty into being. Burnet makes this point most emphatic:

It was ... impossible for Anytus of all men to countenance any violation of the Amnesty. His loyalty to that was beyond all question, since he suffered grievous personal loss by refraining from demanding restitution of his property confiscated under the Thirty, as we know from a speech of Isocrates which belongs to this period. $56^{2}$

We have already mentioned the story of what happened to the man who attempted to do so. Furthermore, if Anytus had presented his demands in a court of law, it is very likely he would have been slapped with a countersuit charging him with violating the law of Archinus, which provided for a demurrer proceeding to take effect if the counterclaim alleged that such a suit for restitution violated the terms of the Am-

56 Burnet, op. cit., p. 101. 
nesty. This is precisely what the client of Isocrates did. What Burnet is suggesting is that Anytus could have violated the law, but did not.

Another point: Isocrates' client describes Anytus' financial losses as large--not grievous, or grave. 57 The size of his loss indicates a wealthy man, which in fact Anytus was. To a man of lesser wealth such a forfeiture might have been devastating; to the impecunious the loss of any sum is critical. Anytus' willingness to write-off his losses proves as much about his loyalty as it does about his bank account--perhaps he had plenty to spare. At least, he was in a better position than most to recover. His wealth was not tied up in land and livestock. He did not have to wait on the seasons for his crops to come in and his livestock to foal. He was a craftsman, a tanner. It is unlikeIy that he fled to Boeotia--which was cattle country--without contacts, without a dime in his pocket. His wealth--in gold and silver cups ${ }^{58}$-was portable. He was likely on his return to have recovered portions of his property and with the right application make good his losses in a comparatively short amount of time. His immediate elevation to high office suggests that this is in fact what happened. So

57 Taylor, op. cit., p. 102 .

${ }^{58}$ plutarch, op. cit., 4. These are listed as being in Anytus' possession. 
far as the evidence permits, he followed the line of least resistance, like everyone else, and obeyed the law.

Even if, for the sake of argument, it is granted that his forfeiture constitutes an investment in the Amnesty, it still does not follow that he was, therefore, a patriot, a loyalist. Traditionally, the landowners of Attica, those who raised the crops and livestock, were oligarchs. As a tanner, Anytus was dependent on them for the hides that kept him in business. While outfitting an army for a foreign war might prove a boon to leather suppliers, civil war was entirely another matter. It sliced the market in half. Internacine fighting had to stop. To a businessman in Anytus' position, Amnesty meant prosperity. His economic survival was dependent on all sectors of the community, regardless of politics. He could not "countenance any violation of the Amnesty" indeed, because a fresh outbreak of violence meant further disruption of the city's economy and a threat to his livelihood--which had suffered enough in his absence. The idea that he would renounce his own self-interests for the good of the city is something one might applaud in a penniless philosopher but not presume of a businessman.

Anytus' reputed zealousness to heal the wound of civil conflict is invoked to explain his support in the defense of Andocides. This is another instance where the criterion used in the theory is so desperately loose that it often unravels to prove just the opposite. In the course of his 
defense, Andocides stakes out a claim that the law, which he is accused of having violated, was voided by the Amnesty. Because of this issue, Anytus' appearance on his behalf is naturally credited to his role as champion of the Amnesty. of course, we don't know why he was there, just that he spoke as an advocate for the defense. There were other issues, besides the Amnesty, involved. But every last ounce of mileage is squeezed from his appearance.

It is employed, in the first place, to prop up the inference from the Isocrates' speech, that Anytus promoted the Amnesty; then, with this supposition firmly in hand, his support of the Amnesty is given as the "reason (why) Andocides was able to call on him to speak for him..."59 and, it is advanced to prove he was not a "religious fanatic." 60 we have already pointed out that the first two uses are neither arguments nor evidence, but testaments of faith. Andocides was up on an impiety charge and it is left for us to believe that if Anytus was a religious fanatic he would have been over on the other side with the prosecution, like Meletus. Andocides is the litmus test for fanaticism. Meletos comes out fanatical because he prosecuted two impiety cases in the same year. Anytos spoke against one and supported

59 Burnet, op. cit., p. 101.
$60_{\text {Taylor, op. cit., p. } 102 .}$ 
another: his religious views are in balance. That takes care of religion. But what part was claimed for Anytus in the case of Socrates? "It (was) the business of Anytus, as chief promoter of the Amnesty, to see that its conditions were not explicitly contravened."6I And he spoke in favor of Andocides because "it was ... impossible for Anytus of all men to countenance any violation of the Amnesty." By the same criterion that was used to settle the religious issue, Anytus appears condemned of the charge of "political fanaticism;" Meletus is acquited. Taylor has hoisted his hero on his own petard.

The Theory Comes Unglued

Anytus' vigilant regard for the Amnesty, as indicated earlier, is used by political motive theorists to explain why no specific reference to the political motive can be found in the Apology. The matters which weighed most heavily with Meletus dated back to the old scandals of 415 . Socrates'neutrality during the revolution and his former relations with Alcibiades and Critias were--it is said--what ultimately moved Anytus to file suit. These were the real grounds for the indictment, but the Amnesty stood in the way of their explicit mention. Some, like Chroust, ${ }^{62}$ hold the

$$
\begin{aligned}
& { }^{61} \text { Ibid., p. } 110-11 \\
& { }^{62} \text { Chroust, op. cit., p. } 171 .
\end{aligned}
$$


opinion that the religious charges entered in court were trumpery--but, most stop short of saying this; they prefer to refer to the charges as ostensible; the real charge is political. This distinction permits a certain ambiguity of treatment. The prosecution could not in open court legally confront Socrates with his crimes, so they selected an indictable offense on which he was peculiarly vulnerable; one which, furthermore, reflected their honest beliefs and yet referred in an obscure way to the underlying cause of the suit--so the jurors could understand what was really meant without it really being said. ${ }^{63}$ with this as their premise, these theorists work both sides of the street, now the religious motive, now the political motive--suddenly everything is explanable.

of course Socrates understood all this quite well, and his defense against Meletus is chiefly devoted to showing that he really meant what he did not venture to say, or rather perhaps, what Anytus would not allow him to say.

One wonders how well Socrates did understand it. Taylor mentions his puzzlement "as to the particular kind of harm he is accused of doing," and speculates that this was the result of the vagueness of the accusations made against him by the prosecution. 65 At any rate, if socrates was wise to

${ }^{63}$ Frederick Copleston, S. J., A History of Philosophy, vol. 1 (Garden City, New York: Image Books, 1962), p. 135.

64 Burnet, op. cit., p. 101.

65 Andocides II. $71-2$. 
the charade his recognition of it was as obscure as if he too had been a party to the cover-up.

By contrast, in his own case, Andocides addressed the issue forthrightly:

Cephisius here informed against me according to the law now in force, but his accusation belonged to an earlier law proposed by Isotimides, which does not concern me (because of the Amriesty).66

This was exactly the situation in Socrates case--according to the political theorists--only the relevant document in his case was the decree of Diopeithes. In Socrates' trial, it is said, the prosecution "studiously avoided ... everything that could suggest the psephism of Diopeithes." 67 But Socrates does not mention the decree, nor does he challenge, like Andocides, the legality of the proceedings. There was certainly nothing to prevent him from opening up and taking the position Andocides took, that the suit was in violation of the Amnesty and therefore one which the court could not legally entertain. He was completely free to do as the client of Isocrates did, file a demurer motion challenging the legality of the proceedings against him. According to the political motive theorists he could have raised a challenge on either count: the charge of irreligion because it dated back to 415 , and the political count because it had nothing

${ }^{66}$ Andocides II. $71-2$.

67 Burnet, op. cit., p. 101. 
to do with his activities after the Amnesty. That he failed to undertake either of these alternatives suggests he either had a fool for a client or did not see the charges brought against him in quite the same light as modern theorists. None of the ancient sources hints at the idea that the Amnesty forced the prosecution to couch the indictment in terms intended to conceal a motive. After the trial was over the lid was off, anyone was free to make this claim-if it was true. The bugaboo of the Amnesty, which requires us to "read between the 1 ines," 68 is a modern invention. There is other evidence--from Xenophon, though he doesn't draw this conclusion--that socrates may not have been tried according to the outdated psephism of Diopeithes but one of a more recent origin, signed into effect by, paradoxically, those with whom he is said to have been so influential, Critias and the Thirty. This particular law-again, according to Xenophon ${ }^{69}$--forbade the "art of debate" and was legislated to silence Socrates' criticisms of the Thirty. This story is probably apocryphal because it too closely parallels the charges on which socrates was actually indicted. But some ${ }^{70}$ have repeated the story without giving any indication that it might be suspect. In defining the

${ }^{68}$ Taylor, op. cit., p. 108 and 111.

69 Memorabilia i.2.31

${ }^{70}$ Taylor, op. cit., p. 101. 
"art of debate" editors will note that it was "making the worse (appear) the better case."71 But Xenophon's remark that Critias passed the law "out of spite towards Socrates, having no handle against him except misrepresenting him to the public by applying to him the usual layman's allegation against all philosophers" (Memorabilia $i, 2,32$ ) is a paraphrase of Apology 23d, where Socrates says his accusers "fall back on the stock charges against any philosopher," and he enumerates them, "that he teaches his pupils about things in the heavens and below the earth, and to disbelieve in gods, and to make the weaker argument defeat the stronger." Clearly what Xenophon has in mind when he refers to the usual layman's allegation is those enumerated by socrates. This was the way he was caricatured by Aristophanes in the Clouds; and the first thing that came to the mind of the Syracusan in Xenophon's Symposim $(6.5-7)$ :

Socrates, are you the person that they call the thinker?

That's nicer than if they called me the thoughtless, (Socrates) replied.

Yes if you weren't regarded as a thinker about things that are too high for us.

Do you know anything higher than the gods?

No, no, said the (Syracusan), its not in them that you're said to be interested, but in the things far above our heads.

In addition, Critias specifically forbade Socrates from conversing with the young. So if one took Xenophon at his

${ }^{71}$ Hugh Tredennick (Tr.) Xenophon: Memoirs of Socrates (Baltimore: Penguin Books, 1970), p. $39 \mathrm{n} 9$. 
word, it would appear that the conduct of Socrates annoyed the oligarchs. Those who maintain that he was put "to death because he had been the teacher of Critias" are faced with irony that Critias' misrepresentations may have laid the groundwork for his "teacher's" later prosecution by the democrats. Perhaps this also explains why Anytus was determined that the accusations should be left "vague and obscure" --and all reference to Critias avoided. Knowing that "owing to (Socrates') vehemence in argument, men set upon him with their fists or tore his hair out; and that for the most part he was despised and laughed at," 72 Anytus could count on the reputation of Socrates, that his prosecution would not prove unpopular with either oligarchs or democrats.

If Xenophon's story of Critias' attempt to silence Socrates is rejected because it too closely mirrors what Anytus apparently hoped to accomplish through his lawsuit-which sets up a parallel between Critias and Anytus--there are still other accounts of Socrates at odds with the Thirty. From the gospel according to Plato there is Socrates' story in the Apology of his refusal to comply with the order to arrest Leon, to which he adds, "I should probably have been put to death for this, if the government had not fallen soon afterward. There are plenty of people who will testify to

${ }^{72}$ Diogenes Laertius, op. cit., II.21. 
these statements" (32e). Diodorus (XIV.4.5) relates that, when Critias gave the order to liquidate Theramenes, Socrates, whom he describes as a friend of Theramenes, attempted to intervene and prevent the order from being carried out. Anytus, was a friend of one (Letter VII,325c) and a political ally of the other (Ath. Con. 34.3). This curious chain of events suggests that prior to the revolution of 404-3 Anytus and Socrates were political comrades of Theramenes. Was Anytus unaware of this connection when he sued socrates because of his doubtful loyalty to the democracy? Had he not, in exile, heard the stories that we hear of socrates' resistence to the Thirty? This whole line of conjecture is further complicated if an attempt is made to establish these events in their proper sequence.

The reign of the Thirty was brief, only eight months. In that short period of time four events occurred which if we knew their chronology might help us untangle the destinies of the antagonists in the trial of socrates. The four events are: 1) the exile of Anytus; 2) the arrest of Leon of Salamis--Anytus' friend, in whose arrest socrates refused to take part and Meletus--it is said--complied; 3) the proscription against the "art of debate" by Critias; and 4) Critias' ordered execution of Theramenes--Anytus' political associate and Socrates' friend. Now if Anytus' exile preceded the other events, it could be said that he had no first-hand knowledge of Socrates' opposition to the Thirty 
and, so, instituted the (political) proceedings against socrates in good faith; conversely if his exile followed these events, he could very well have known of the gag order placed on Socrates, of possibly Critias' misrepresentations; of Socrates' refusal to arrest Leon, of Meletus' complicity; and of Socrates' attempted intervention on behalf of Theramenes. What would that sequence make of the political motive? Of course, his presence or absence would not necessarily assure any of the above consequences; but assigning a definite date to his exile in relation to the other events, or the other events in relation to his exile, would create a strong presumption that could be of use in the marshalling of circumstantial evidence. 73

These four events give way to sixteen possible combinations, from which conceivably a like number of conclusions --if not more--could be drawn. Even if--in order to prune down the number--we reject as fiction Xenophon's story of

$73_{\text {This }}$ is a variation of the Wittgensteinian outlook that "problems are solved, not be giving new information, but by arranging what we have always known .... The work (of a philosopher) consists in assembling reminders for a particular purpose." Ludwig Wittgenstein, Philosophical Investigations, Third Edition, (New York: The Macmillan Company, 1969), p.p. 109 and 127. 
the proscription ${ }^{74}$ (he is our only source for it), and Diodorus' story of Socrates' attempt to save Theramenes (for the same reason), and assume Xenophon's (Hellenica II-III) chronology for the other events is correct, namely, that Anytus' exile and Leon's death preceded the execution of Theramenes; we still do not know the order that the former events fell in and are left with the riddle of Socrates' statement that he would have been put to death for defying the order to arrest Leon if the government of the Thirty had not been overthrown "soon afterward." 75 One would assume that, being a wealthy metic, Leon's death occurred early on in the reign of the Thirty--because foreign residents were the first to be killed--and yet socrates informs us that the government fell soon after his death. Was Socrates (Plato?) fibbing? If those who accept Plato as gospel believe Socrates' statement is true, then perhaps Xenophon's account is in error: Leon's death occurred very late in the reign and much after the death of Theramenes. Either that; or Leon's death, Theramenes' execution and the ouster of the Thirty went down like dominoes in rapid succession. The sources we rely on give little clue as to how these events came toge-

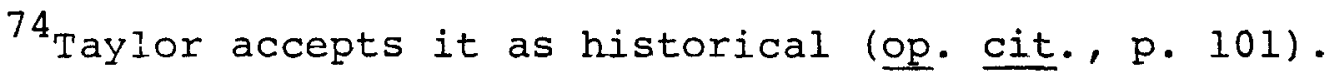

${ }^{75}$ Guthrie, op. cit., repeats this story and then adds, "He was saved from the consequences of his action by the counter-revolution which restored the democracy"--without a trace of irony. 
ther, but certainly if any or all of these stories are believed historical, then a chronology explaining their relation to one another must be provided. If they are willynilly lumped together they are nothing more than isolated episodes--the historian becomes a teller of tales, his conclusions nothing more than morals appended to fables.

With Theramenes as the connecting link, it appears that Anytus and Socrates shared a similar political point of view prior to the revolution. Further, they both joined in the resistance: Socrates--after his fashion, and Anytus as a counter-revolutionary. Assuming such a state of affairs, several conclusions follow:

1. Anytus did not hold Socrates responsible for the conduct of Critias or the Thirty.

2. Anytus quarrel with socrates did not originate until after the democracy was restored. Therefore, events preceeding the Amnesty were not the "real gravamen" 76 of the suit.

3. Anytus' indictment of Socrates was not politically motivated but arose out of personal differences.

This last conclusion is usually rejected, or underplayed, because it seems to leave only Xenophon's story that Socrates provoked Anytus with his criticism of bringing his son up in a tannery. This seems too petty for a man of Anytus' stature. ${ }^{77}$ But the motive suggested by Xenophon--

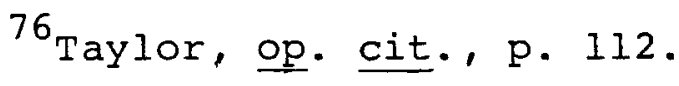

${ }^{77}$ M. I. Finley, op. cit., p. 61, however, rejects the political theory. 
whether derivative or original--finds support in the Meno by Plato.

This dialogue, in which Anytus figures, is supposed to have occured "only a year or two before the trial" ${ }^{7}$--which poses no conflict with the suggestion that their dispute was of recent origin. Burnet contends that the Meno reveals Plato's conviction that the trial was politically motivated. "Plato means us to understand that, in his view, the prosecution of Socrates by Anytus was due to his disparagement of democratic statesmen," and more, that the criticisms of Socrates "must have seemed dangerous to him ... (because) Anytus and his friends were working hard to restore the ... moderate democracy of the days before the Peloponnesian War." In other words, Socrates was suspected of harboring oligarchic sympathies, such as those which were said to have greatly influenced Critias and Alcibiades; and so long as he remained an influence in the city, he posed a threat to the democracy. This fits in well with the political theory, but it overlooks the fact that Socrates' criticisms in the Meno are clearly directed at Anytus personally; and the latter's abrupt and angry departure is not because he senses political heresy in the air but because he has been insulted.

The sense of this dialogue has been so wilfully distorted that it seems necessary to review it in some detail. 
Anytus is introduced by Socrates as the son of a good and virtuous father. He then goes on to argue the position-using "good statesmen" as an example--that good men usually fail to pass on their virtue to their sons. ${ }^{79}$ The implication of what he is saying to Anytus is clear, You may think you're pretty good because you've been elected to high office. You imagine yourself to be a Themistocles, or Aristides, or Pericles. But look how their sons turned out. No, Anytus, virtue cannot be taught. Your father was a good man but you don't cut it. ${ }^{80}$ It is this that infuriates Anytus, which sends him off with a threat in his teeth. And what is Socrates' comment to Meno? "He thinks I am slandering our statesmen, and moreover he believes himself to be one" (95a). He believes Anytus is full of puffed-up pride and punctures it with ridicule. This is the theme of the remarks in Xenophon (Apology 29); but there Socrates lances his pride by making fun of the "education" he gives his son. Burnet's suspicion that the latter "is only an inference from the Meno" contradicts his claim that "we hear nothing in Plato of the merely personal motives attributed to Anytus

${ }^{79}$ The irony is that the sons of socrates never achieved any fame. Furthermore, the pride he saw in Anytus could very well have been his own.

${ }^{80} \mathrm{Jacob}$ Klein, A Commentary on Plato's Meno (Chapel Hill: the University of North Carolina Press, 1965), p. 224, confirms this reading. 
in Xenophon's Apology." The theme of both--whether it's statesmen or tanners--is clear: Socrates believed Anytus' newly found status had gone to his head.

But let it be assumed, for the sake of argument that Anytus did not take Socrates' remarks personally, but took them as a threat to the democracy. What would those who advocate this view be telling us about his mental makeup? That he took a personal insult as an attack on "one of the leading statesmen of his time:" was his dignity so stung that he could only imagine such ridicule coming from a renegade of democracy; who had to be weeded out--not on his account--but because he posed a danger to democracy. What are we to make of this self-conceit? Only a bigotted sort of politician with an overindulged and overinflated ego would be capable of such presumption. Furthermore, if he could react in this vein to an insult evolved through the filter of dialectics, how might he respond to something more direct; like, all I said was "that he ought not to educate his son in a tanning yard! What a villain he is!" ((Xenophon) Apology 29).

So our great man may not have been so moderate afterall, not so very prominent and--can it be said?--not much of a democrat. 


\section{CHAPTER IV}

\section{DIGRESS ION}

Both Anytus and Socrates came out of the same workingclass tradition. Their families were neither aristocratic nor adorned with the ornaments of distinguished ancestry. Without inherited wealth, their fathers had to rely on their own wit and labor to make a living.

Anthemion, the father of Anytus, began as a simple tanner and over the years transformed his humble beginnings into a respectable cottage industry (Meno 90 a). His customers were wealthy aristocratic landowners, whose sheep and cattle provided the hides for his tannery. The leather which he subsequently produced was traded or sold for goods or services or hard currency. He was a modest man, hard working and well respected (Meno 90a). His growing prosperity and business contacts opened the doors of society to him. But his money, however earned, was still new, and, in some circles, he was looked down upon as an upstart, a common leather-seller. ${ }^{81}$ His money had opened the door, but it

${ }^{81}$ Victor Ehrenberg, The People of Aristophanes (New York: Barnes \& Noble Books, 1943), p. 121. 
would have to age a generation until the newness wore off and the times had changed. And then it was the son, Anytus, and not the father who passed through the door.

If Anthemion was an ant, Sophroniscus, the father of Socrates, was a grasshopper. A stone-cutter, his legacy to his son was genetic. One tradition informs us that Socrates learned the trade of his father and began his career in a workshop. Like Lana Turner, he was discovered there by Crito, a man of means, who was struck by the "beauty of his soul" 82 and became his patron. This tradition attests to Crito's generosity. It is said that he invested 7,000 drachmas as an endowment for socrates, ${ }^{83}$ which at 12 percent per annum--which was the going rate 84 --would have more than doubled any earnings he could have made in his prime as a stone-cutter. ${ }^{85}$ At any rate, socrates became a pupil of first Anaxagoras and then Archelaus, the leading sophists in Athens; and it was in their company that he first began to make a name for himself among the sons of the well-to-do. Later, he was to renounce the cosmological trend of their teaching for his own particular brand of philosophy, but

${ }^{82}$ Diogenes Laertius II. 21.

${ }^{83}$ Plutarch, Aristides 1.

${ }^{84}$ Aristotle, Athenian Constitution 52.2.

${ }^{85}$ Ehrenberg, op. cit., p. 231. 
their teaching and society left a stamp on him as sure as his humble beginnings.

Professional teachers were something new to Athens in the $40^{\prime} \mathrm{s}$ and $30^{\prime} \mathrm{s}$. Not only were these men a challenge to the old system of education--which up to then had been primarily one of experience, handed down from father to son, from generation to generation--but they were also foreigners with foreign ideas. Never once were they allowed to become citizens and take an active part in civic affairs. They were always pariahs--outsiders--in their adopted city; there by the grace of the rich--and their teaching mirrored their condition.

Anytus moved in somewhat different circles than socrates, but occasionally their paths would cross. Plutarch tells a story that at one time they were rivals for the hand of Alcibiades, a romantic competition in which socrates was declared the winner. 86

One of the curiosities about Anytus is that we know virtually nothing of his military record during the Peloponnesian war. Socrates served in the infantry in at least three campaigns. Of Anytus, all that is known is that in 409 he was sent as general in aid of thirty ships under attack by a Lacedemonian fleet off the coast of Pylos. At the Malea Promontory--still far from his destination--he was

${ }^{86}$ Plutarch, Alcibiades 4. 
hit by a storm and returned to Athens. The democracy was not as tolerant then as it was to be later. He was indicted for treason, and if he hadn't spreadhis money among the judges very likely he would not have survived to prosecute Socrates. ${ }^{87}$ This story could well be a fiction--and if it is that, then nothing at all is known of his record during the war. To have received a commission he would have had to be at least thirty years old, there was still plenty of fighting left if he was to make his mark. Since Alcibiades was born circa 450 this would have made their romance somewhat difficult, so it must be presumed that he was older than thirty when he was assigned to Pylos. Nevertheless, we hear nothing of him prior to 409 or after; not until 404 does he surface again.

Diodorus' story suggests a man of considerable means. Only the rich became generals, ${ }^{88}$ and only the super-rich could afford to buy off a jury, whose numbers were often 200 to 500 and up. Regardless of his military ability, or lack of it, Anytus, because of his wealth, would surely have been expected to contribute his share to the yearly festival entertainments, athletic competitions and expenses of war. These could become quite high. One man reports (Lysias XXI)

${ }^{87}$ Diodoros Siculus, XIII.64.6

${ }^{88}$ Ehrenberg, 으. it., p. 108. 
that in a three year period $(410-08)$ he spent over 11,000 drachmas on the first two alone; his outlay for military costs from 411 to 404 amounted to 36,000 . When a man worth 6,000 drachmas was considered wealthy, 89 the oligarch's (the wealthy's) machinations to end the war and government handouts, that were bleeding them dry, are more inteligible. Anytus must certainly have been sensitive to the squeeze they were in, and so, following the war, joined the coalition that supported the reforms of Theramenes.

Then he was driven out by the Thirty and his property confiscated. Suddenly he pops up again as general, among the exiles. But it is not he who turns back the knights at Phyle, or captures the hills commanding the harbor of Piraeus. One suspects his primary function was administrative, capital and supply acquisition. As a businessman this is where his talents would lie. And when the democracy was restored he carried on in that capacity. It should not be thought--it seems--that as a general of the democracy he was a visible leader, a firebrand. There is no evidence to suggest that he was a public speaker, a demagogue. It should not be missed either that he rose to the top when Athens was at its nadir, its empire crushed, its citizenry at war with itself.

${ }^{89}$ Ibid. , p. 237. 
Meanwhile, what was Socrates doing during this time; what sacrifices had he made; what losses had he suffered? According to Xenophon (Apology 18), he could boast at his trial that, "during the siege when others were feeling sorry for themselves, I was in no worst straits than when the state was at the height of its prosperity." Socrates made a display of his poverty, he wore it on his sleeve. He had a house, a slave (maybe more), a wife (maybe two) and three sons, and he provided for them. It was not that he had to watch every penny; he had friends, pupils, who gave him-not money--but gifts, he could accept or decline them as he pleased. 90 He could ridicule the sophists for taking payment, they were foreigners who either had no other means of support or, like a businessman, had an eye for a buck. Socrates, after his fashion, was an upstart himself. He represented a new fashion in education just as Anytus represented a new fashion in politics. Prosperous merchants, such as Anytus, were beginning to invade the ranks of the aristocracy, whose wealth and numbers were in decline. They were now in direct competition for the same civic honors which, formerly, had been the aristocracy's alone. Suddenly there was Kleon, a tanner, elected to the highest post in government; then Hyperbolus, a lamp-seller; and Kleophon, a lyre-maker. The old buddy system was breaking down. And 
Socrates, in his own way, was lending a hand. He seemed not to like to see the old system go. These upstarts with their new money and their know-it-all ways seemed to grate on him. He wanted to drop them down a notch or two. He, after all, had earned his reputation; he had proved himself. To him Anytus--simply--inherited his position (Meno 90a).

They were both proud men. The similarities in their background seemed to intensify their differences. The annoying ridicule of a man of beggerly appearance, proud of his poverty, who made no effort to improve his circumstances, 91 must have grated on a man of Anytus' position. Plus, Socrates seemed to cast a spell over people which must have seemed incomprehensible. And it could very well be that one of those he cast a spellover, for a time, was the young son of Anytus.

Socrates was indicted for corrupting the young. During the course of his defense, he reminds the court of Anytus' warning that if Socrates was not put to death he would continue to "demoralize" the sons of Athenians (Apology 29c). This charge would have more poignancy if one of the sons in question happened to be Anytus'. Socrates, according to Xenophon (Apology 30), had attracted the boy at one time. "Once for a short time I associated with Anytus' son, and I

91 Thucydides, op. cit., II.vi.40. Pericles regards such a thing as disgraceful. 
thought that his son was not weak in soul. So I told him not to stay in the slavish employment that his father had prepared for him" Anytus was from the old school of education: he believed a son should be brought up in the business of his father, learning a trade, ${ }^{92}$ not idling around in the marketplace having his head crammed full of useless ideas. His son's drinking habit suggests that he was becoming something of a dandy, affecting the vices associated with the aristocracy. ${ }^{93}$ This could very well have been the result of the crowd he ran with, not the effect of Socrates' teaching, but the father would be quick to find a scapegoat to deflect the blame of upbringing. It might have stuck in his mind, too, that long ago Socrates had stolen a loved one from him, a heavy drinker; and the thought that this may be happening again, with his own son, perhaps drove him to revenge.

\section{Anytus' Selection of Meletus}

Now those who hunt under every tree and branch looking for a political motive usually find in Anytus' choice of Meletus to represent the case, another attempt on the part of the statesmen to conceal the root cause of his complaint.

92 Gustave Glotz, Ancient Greece At Work, (New York: The Norton Library, $1967, \mathrm{p} .163$, indicates that this was in fact prescribed by law.

${ }^{93}$ Ehrenberg, op. cit., p. 102. 
Not only must the motive be concealed, but its bearer must remain in the shadows with it.

Anytus was the moving spirit; but, if he had appeared as the principal accuser, it would have been difficult to avoig giving the prosecution a political appearance.

Who this dodge was intended to fool is an interesting question. The two men who stood up in court to speak in support of the poet's (Meletus') suit were both politicians. It must also be remembered that by some accounts virtually everyone that day was aware that socrates was not on trial for the reasons stated in the accusation. The emperor had no clothes, but no one was about to protest. Political trials often do take on a sham aspect, but with no one to deceive, there is no chicanery. Anytus may, indeed, have had something to hide, but since both he and Lycon appeared at the trial, it is extremely unlikely that the political motive was it.

The use of a "front" in criminal proceedings was common enough in Athens. Thucydides tells us that when Alcibiades was under suspicion for hispart in the profanation of the mysteries, his enemies put "forward other orators" 95 to propose that he should be allowed to sail to sicily and, if necessary, tried on his return. Plutarch adds that orators

94 Burnet, op. cit., p. 151 (36a8). Ditto Taylor, op. cit., p. 123.

95 Thucydides, op. cit., VI.xviii. 30. 
were chosen because they were not known to be enemies of Alcibiades. 96 Again, Thucydides relates that before the oligarchs openly seized control of the Assembly and Council in 411, they "both supplied the speakers, and reviewed in advance what they were to say" before these bodies. 97 Theramenes and "his supporters" are said to have bribed a man to bring the accusation against the generals of Arginussae befor the Council. 98 Theramenes had himself been involved in the disaster, and, in order to take the heat off, he defended himself by attacking others. A similar diversionary tactic was employed by Crito, supposedly at the instigation of socrates. Wealthy men were frequently the target of predatory lawsuits. Instead of risking a jury verdict, they would usually settle with their accuser out of court. This was a form of blackmail. Crito hired another man to blackmail his blackmailer, and put an end to the suits. What is interesting is that Crito did not pay his "front," but recompensed him with gifts and presents. 99 The "front" in the case of Andocides, however, was paid-1,000 drachmas--and his employer showed up at the trial as one of the advocates

${ }^{96}$ Plutarch, Alcibiades 19.

97 Thucydides, 요. it., VIII.xxxv.66.

${ }^{98}$ Xenophon, Hellenica, I.vii.9.

99 Xenophon, Memorabilia, ii.9. 
for the prosecution. 100

Now to which of these instances is the use of Meletus by Anytus analogous? It is, of course, impossible to say. What is common to all of them, however, is 1) the "front" was compensated and 2) the actual plaintiff was protecting his own self-interest. Against this background, it is difficult to believe that Anytus would go to the expense of prosecuting Socrates for the good of the state.

It was necessary for Meletus that his services were made worth while, because a false accusation was a criminal offense. ${ }^{1}$ Had he and Anytus failed to garner one fifth of the juror's votes, they would have received a fine of 1,000 drachmas. $^{2}$ Anytus had lost a large sum of money four years previously; but here he was willing to gamble a 1,000 and, moreover, pay another to gamble it for him. The expense seems an enormous price to pay for the satisfaction of getting even with Socrates, but to a man capable of bribing juries wholesale, perhaps the ante of a single suit was chicken feed. His demand of the death penalty, on top of the sum he was willing to risk, indicates, however, that he subscribed to the code of total retaliation. Socrates had

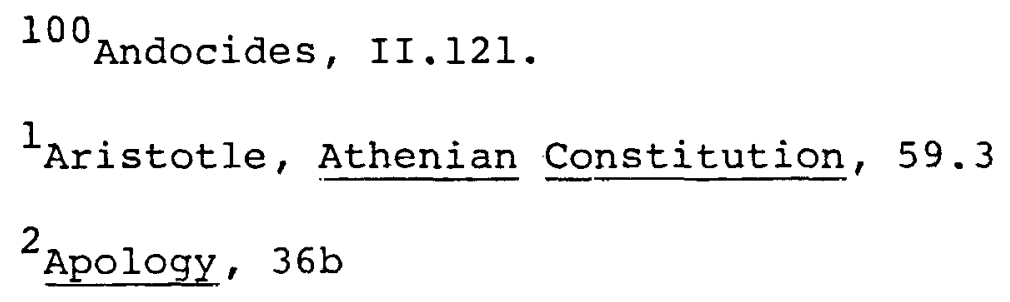


belittled him because of the pride he took in his status; a man devoid of "human feeling" ${ }^{3}$ might take cynical pleasure in showing his detractor just how great that status could be, if it all of a sudden descended in one blow on a prattling pauper.

3 (Xenophon) Apology, 31. 
CHAPTER V

\section{PERORATION: A SUMMARY}

This thesis has argued that a study of the sources relating to the accusers of socrates does not support the theory that the prosecution looked to rid Athens of a political enemy when it indicted Socrates on the charge of irreligion.

The political theory has assumed that Meletus, as a member of the Eumolpidae priesthood, held the atheistic teachings of Socrates responsible for the conduct of Alcibiades. As a representative of the clan, he was embittered over Alcibiades' irreverent parody of the priesthood in the notorious scandal of 415. His prosecution of Andocides in the same year on the same charge is taken as the strongest proof that he regarded the teachings of Socrates as having a demoralizing effect on the youth of Athens.

The Meletus who spoke against Andocides was the descendant of the ancient Eumolpidae, but, also, the one who had served the Thirty in the arrest of Leon of Salamis. Socrates, who was there at his side when the order of arrest was given, does not include his accuser in his account of the incident, nor does he admit to having known of him prior to the prosecution. Socrates' forgetfulness would be even more unlikely if Meletus had conducted an impiety case only 
a few months before he joined in the attack on socrates.

The chronology of the two trials also makes it difficult to understand why a man of sense and standing, like Anytus, would have picked a fire-breathing religious fanatic to press the suit against socrates. Furthermore, it is incomprehensible why he should have sided with an accomplice to the murder of his friend, Leon, and a man, too, who had remained in the city, like socrates, during the difficult time of the revolution.

Anytus shared Meletus' loathing for the sophistical teachings of socrates, but he was more concerned with the political consequences than the religious effects. Alcibiades, after all, had actively aided the enemy. His intimate knowledge of Athenian military weaknesses, and advice to the Spartans, directly contributed to the downfall of Athens and the destruction of her empire.

While one of Socrates' disciples ruined Athens from without, another, Critias, ruined it from within. Socrates' residence in the city under the tyranny, his apparent immunity from the terror, were thought to have been by the grace of his former pupil's protection. The oligarchic take-over and reign of terror were thought to have been the tenets of his teaching put into practice.

Realizing the danger his extraordinary influence posed to the democracy, Anytus moved immediately, on his return, to have Socrates tried and condemned and driven into exile. 
As the chief promoter of the Amnesty, he was determined to put an end to the smoldering feud that remained between the oligarchs and democrats. And Socrates, with his inveterate criticisms of democratic leaders and institutions, posed a clear and present peril to the uneasy peace that Anytus had worked so hard to realize following the restoration of his party to power.

He could not, however, because of the restrictions of the Amnesty, air these grievances in open court. But while the effects and consequences of Socratic dogma could not be explicitly assailed, the cause of the general demoralization, the man himself, could be. And so, he was tried, and by a slim majority found guilty, and was put to death.

This account of the prosecution's motives has raised the trial of Socrates to the level of high drama. The issue at stake was nothing less than the future of Athenian democracy. But when the accounts were examined, it was discovered that the evidence had been tampered with, and the sources siphoned to promote a theory.

This paper had essayed the sources for evidence of Anytus' leading role, first as a democrat and then as a leader of the restored democracy, and found it wanting. Moreover, the various attempts to cast him in a favorable light were seemingly bankrupt. They were not rational but emotional appeals, and all conformed to the same pattern: he was a moderate because: Meletus was a religious fanatic, the 
Thirty were political temorists, because he did not break the law, and did not want the death of Socrates. He was, by all accounts, the ideal statesman, a worthy representative of democracy, a fit opponent of socrates.

However, the sources were unable to sustain the image. The picture of his political committment was blurred by his association with Theramenes and his business ties to the oligarchs. His compliance with the Amnesty seemed to reflect more the realities of the business world than the act of a highminded diplomat. His moderate repute was tarnished by his rush to judgment and the severity of the penalty he invoked. The moderation of "his" government was relative, not absolute, and its excesses were overlooked--possibly because they would have had to be his as well. By the same token, the stories alleging a personal vendetta were similarly swept under the rug, because they did not comport with the image of the man of "no worthy motives," who would rather grieve over his lost money than take the law into his own hands.

It seemed, too, that at one time he and Socrates were in political agreement, and both active in their resistance to the atrocities of the Thirty--Socrates, appropriately, from within, Anytus from without. Their common opposition to the dictatorship seemed to belie the theory that political events drove them apart.

Anytus rose like a phoenix from the ashes of his city's defeat. His wealth made him singular, not ideal. He was 
still, afterall, whatever his social standing, a creature of flesh and bone, who could be damned one day and divine the next. His near apotheosis has blunted the evidence of human complexity, of change, of personal failing. The spurned motive of self-interest is requisitioned to prop up the temple of democracy. He was its servant; Socrates its critic. Those who have sought to rectify his image have cast him into a column of stone, a pillar of society. Socrates, with his intellect as a chisel and his will as a hammer, in working on Anytus, chose the object of his art unwisely. When the pillar gave way, the temple toppled and crushed the stone-cutter. 


\section{A LIST OF WORKS CONSULTED}

Allen, Reginald E., (ed.), Greek Philosophy: Thales to Aristotle (New York: The Free Press, 1966).

Beckman, James, The Religious Dimension of Socrates' Thought (Ontario: Wilfrid Laurier University Press, 1979).

Bowra, C. M., The Greek Experience (New York: A Mentor Book, 1957).

Burnet, John (ed.), Plato's Euthyphro, Apology of Socrates and Crito (Oxford: The Clarendon Press, 1924).

Bury, J. B., and Meiggs, R., A History of Greece, Fourth Edition (New York: St. Martin's Press, 1975).

Cambridge Ancient History, Vols. 5 and 6, 1923-39.

Casson, Lione1, The Ancient Mariners (Minerva Press, 1959).

Chroust, Anton-Hermann, Socrates, Man and Myth (Notre Dame, Indiana: University of Notre Dame Press, 1957).

Copleston, Frederick, S. J., A History of Philosophy, Vol. 1, Part 1, (Garden City, New York: Image Books, 1962).

Cornford, F. M., Before and After Socrates (Cambridge: at The University Press, 1966).

Diodorus Siculus, The Library of History, C. H. Oldsfather (trans.), Loeb Classical Library, 1954.

Diogenes Laertius, Lives of Eminent Philosophers, R. D. Hicks (trans.), Loeb Classical Library, 1925.

Dryden, John (trans.), Plutarch's Lives (New York: The Modern Library, 1932).

Dyer, Louis (ed.), and Seymour, Thomas Day (rev.), Plato, Apology of Socrates and Crito (Los Angeles: Demetrius \& Victor, Booksellers, 1973).

Ehrenberg, Victor, The Greek State (New York: The Norton Library, 1964). 
- The People of Aristophanes (New York: Barnes \& Noble Books, 1943).

Finley, John H., Jr., Four Stages of Greek Thought (Stanford: University Press, 1966).

Finley, M. I., "Socrates and Athens," Aspects of Antiquity (New York: The Viking Press, 1969).

- The Ancient Economy (Berkeley: University of California Press, 1973).

, The Ancient Greeks (New York: The Viking Press, $1964)$.

Friedlander, Paul, Plato: An Introduction (Princeton: Princeton University Press, Bollingen Paperback Edition, 1973).

Glotz, Gustave, Ancient Greece At Work (New York: The Norton Library, 1967).

, The Greek City, (New York: Barnes \& Noble, Inc., 1969).

Gomperz, Theodor, Greek Thinkers: A History of Ancient Philosophy, Vol. II, (London: John Murray, Albemarle Street, 1905).

Gouldner, Alvin W., The Hellenic World (New York: Harper Torchbooks, $19 \overline{6} \overline{9})$.

Grote, George, A History of Greece, Vol. VII, (London: John Murray, Albemarle Street, 1904).

Guthrie, W. K. C., Socrates (Cambridge: Cambridge University Press, 1971).

Hades, Moses, (ed.), The Complete Plays of Aristophanes (New York: Bantam Books, 1971).

Hamilton, Edith, and Cairns, Huntington (ed.), plato: The Collected Dialogues (Princeton: Princeton University Press, Bollingen Series, 1978).

Isocrates, Vol. III, Larue Van Hook (trans.), Loeb Classical Library, 1945.

Jaeger, Werner, Paideia, Gilbert Highet (trans.), (New York: A Galaxy Book, 1965).

Jowett, B. (trans.), The Works of Plato (New York: Tudor Publishing Company, cl900). 
Kennedy, George, The Art of Persuasion in Greece (Princeton: Princeton University Press, 1963).

Kierkegaard, Soren, The Concept of Irony (Bloomingdale: Indiana University Press, 1965).

Kirk, G. S., and Raven, J. E., The Presocratic Philosophers (Cambridge: At the University Press, 1957).

Klein, Jacob, A Commentary On Plato's Meno (Chapel Hill: The University of North Carolina Press, 1965).

Lysias, W. R. M. Lamb (trans.), Loeb Classical Library, 1930.

Murray, Gilbert, Five Stages of Greek Religion (Garden City, New York: Doubleday Anchor Books, 1955).

Nietzsche, Friedrich, "The Problem of Socrates," The Philosophy of Nietzsche (New York: Mentor Books, 1965).

Nilsson, Martin P., Greek Piety (New York: The Norton Library, 1969).

Olmstead, A. T., History of The Persian Empire (Chicago: The University of Chicago Press, 1948).

The Oxford Companion to Classical Literature (Oxford: At The Clarendon Press, Reprinted 1969).

Parke, H. W., Festivals of The Athenians (Ithaca, New York: Cornell University Press, 1977).

Phillipson, Coleman, The Trial of Socrates (London: Stevens \& Sons, Ltd., 1928).

Pomeroy, Sara B., Goddesses, Whores, Wives, and Slaves (New York: Schocken Books, 1975).

Renault, Mary, The Last of The Wine (New York: Vintage Books, 1975).

Richards, I. A., Why So, Socrates? (Cambridge: At The University Press, 1964).

Robinson, Charles Alexander, Jr., Athens in The Age of Pericles (Norman: University of Oklahoma Press, 1959).

Rogers, Arthur Kenyon, The Socratic Problem (New Haven: Yale University Press, 1933).

Rostovtzeff, M., Greece (New York: Oxford University Press, 1963). 
Saunders, A. N. W. (trans.), Greek Political Oratory (Baltimore: Penguin Books, 1970).

Slater, Philip E., The Glory of Hera (Boston: Beacon Press, 1968).

Stone, I. F., "The Socrates Story," The New York Times Magazine, April 8, 1979.

Strauss, Leo, Xenophon's Socrates (Ithaca, New York: Cornell University Press, 1973).

Taylor, A. E., Socrates (Garden City, New York: Doubleday Anchor Books, 1952).

Thucydides, The Peloponnesian War, John H. Finley, Jr. (trans.), (New York: The Modern Library, 1951).

Tredennick, Hugh (trans.), Xenophon: Memoirs of Socrates

(Baltimore: Penguin Books, 1970).

(trans.), Plato, The Last Days of Socrates (New York: Penguin Books, 1954).

Tomlin, E. W. F., The Western Philosophers (New York: Harper Colophon Books, 1963).

Vlastos, Gregory (ed.), The Philosophy of Socrates (Garden City, New York: Anchor Books, 1971).

von Fritz, Kurt and Kapp, Ernst, (trans.), Aristotle, Constitution of Athens \& Related Texts (New York: Hafner Press, 1950).

Webster, T. B. L., Life in Classical Athens (New York: G. P. Putnam's Sons, 1969).

Winspear, A. D., and Silverberg, T., Who Was Socrates? (New York: The Cordon Company, 1939).

Wittgenstein, Ludwig, Philosophical Investigations, Third Edition, (New York: The Macmillan Company, 1969).

Xenophon, Hellenica, Books I-IV, Carleton L. Brownson (trans.), Loeb Classical Library, Reprinted 1968 .

' Socrates' Defense Before The Jury, Anna S. Benjamin (trans.), (New York: The Bobbs-Merril Company, Ina, 1965).

Zeller, Eduard, Outlines of The History of Greek Philosophy, Thirteenth Edition, (London: Routledge \& Kegan Paul, Ltd., 1969). 